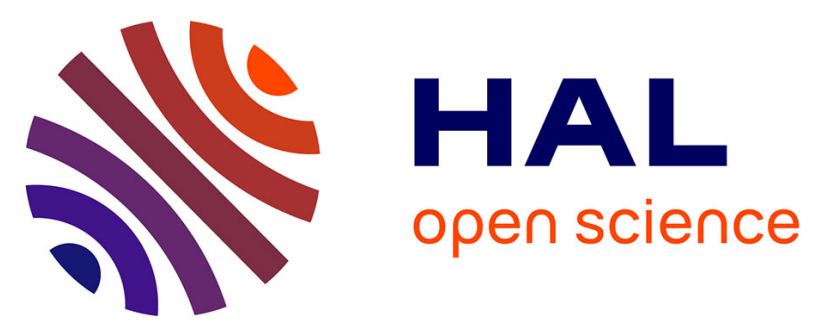

\title{
High-latitude ice and climate control on sediment supply across SW Gondwana during the late Carboniferous and early Permian
}

Neil Griffis, I. Montañez, R. Mundil, D. Le Heron, Pierre Dietrich, C. Kettler, B. Linol, T. Mottin, F. Vesely, R. Iannuzzi, et al.

\section{To cite this version:}

Neil Griffis, I. Montañez, R. Mundil, D. Le Heron, Pierre Dietrich, et al.. High-latitude ice and climate control on sediment supply across SW Gondwana during the late Carboniferous and early Permian. Geological Society of America Bulletin, 2021, 133 (9-10), pp.2113-2124. 10.1130/B35852.1 . insu-03132766

\section{HAL Id: insu-03132766 \\ https://hal-insu.archives-ouvertes.fr/insu-03132766}

Submitted on 9 Apr 2021

HAL is a multi-disciplinary open access archive for the deposit and dissemination of scientific research documents, whether they are published or not. The documents may come from teaching and research institutions in France or abroad, or from public or private research centers.
L'archive ouverte pluridisciplinaire HAL, est destinée au dépôt et à la diffusion de documents scientifiques de niveau recherche, publiés ou non, émanant des établissements d'enseignement et de recherche français ou étrangers, des laboratoires publics ou privés. 


\title{
High-latitude ice and climate control on sediment supply across SW Gondwana during the late Carboniferous and early Permian
}

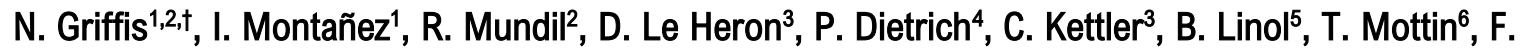 \\ Vesely $^{6}$, R. lannuzzi ${ }^{7}$, M. Huyskens ${ }^{1}$, and Q.-Z. Yin ${ }^{1}$ \\ ${ }^{1}$ Department of Earth and Planetary Sciences, University of California, Davis, California 95616, USA \\ †Present address: U.S. Geologic Survey, Lakewood, Colorado 80225, USA; ngriffis@usgs.gov. \\ ${ }^{2}$ Berkeley Geochronology Center, Berkeley, California 94709, USA \\ ${ }^{3}$ Department of Geodynamics and Sedimentology, University of Vienna, Althanstrasse 14, A-1090 Vienna, Austria \\ ${ }^{4}$ Géosciences-Rennes, UMR6118, Université de Rennes 1, 35042 Rennes Cedex, France \\ ${ }^{5}$ Earth Stewardship Science Research Institute (AEON-ESSRI), Nelson Mandela University, Port Elizabeth 6019, \\ South Africa \\ ${ }^{6}$ Departamento de Geologia, Universidade Federal do Paraná, Curitiba, Paraná 80060-000, Brazil \\ ${ }^{7}$ Departamento de Paleontologia e Estratigrafia, Universidade Federal Rio Grande do Sul, Porto Alegre, Rio Grande \\ do Sul 90040-060, Brazil
}

\section{ABSTRACT}

The response of sediment routing to climatic changes across icehouse-to-greenhouse turnovers is not well documented in Earth's pre-Cenozoic sedimentary record. Southwest Gondwana hosts one of the thickest and most laterally extensive records of Earth's penultimate icehouse, the late Paleozoic ice age. We present the first high-resolution U-Pb zircon chemical abrasion-isotope dilution-thermal ionization mass spectrometry (CA-ID-TIMS) analysis of late Paleozoic ice age deposits in the Kalahari Basin of southern Africa, which, coupled with existing CA-ID-TIMS zircon records from the Paraná and Karoo Basins, we used to refine the late Paleozoic ice age glacial history of SW Gondwana. Key findings from this work suggest that subglacial evidence in the Kalahari region is restricted to the Carboniferous (older than $300 \mathrm{Ma}$ ), with glacially influenced deposits culminating in this region by the earliest Permian (296 $\mathrm{Ma})$. The U-Pb detrital zircon geochronologic records from the Paraná Basin of South America, which was located downstream of the Kalahari Basin in the latest Carboniferous and Permian, indicate that large-scale changes in sediment supplied to the Paraná were contemporaneous with shifts in the SW Gondwana ice record. Gondwanan deglaciation events were associated with the delivery of far-field, African-sourced sediments into the Paraná Basin. In contrast, Gondwanan glacial periods were associated with the restriction of African-sourced sediments into the basin. We interpret the influx of farfield sediments into the Paraná Basin as an expansion of the catchment area for the Paraná Basin during the deglaciation events, which occurred in the latest Carboniferous (300-299 Ma), early Permian (296 $\mathrm{Ma})$, and late early Permian $(<284 \mathrm{Ma})$. The coupled ice and detrital zircon records for this region of Gondwana present opportunities to investigate climate feedbacks associated with changes in freshwater and nutrient delivery to late Paleozoic ocean basins across the turnover from icehouse to greenhouse conditions. 


\section{INTRODUCTION}

Icehouse climates are atypical across Earth's history, with only three occurring in the past half billion years of the Phanerozoic. Despite their less common occurrence, icehouse climates have a profound impact on the hydrologic cycle, seawater chemistry, and evolution of continental crust, ultimately impacting our interpretation of the geologic record (Montañez and Poulsen, 2013; Keller et al., 2019). The transitions from icehouse to greenhouse climates are characterized by climatically sensitive glaciers that are highly erosive and associated with increased rates of sedimentation in basins (Dowdeswell et al., 2010) and complex subglacial records (Le Heron et al., 2019). Importantly, these icehouse-togreenhouse transitions are associated with major reorganizations of continental-scale drainage systems, thus controlling the delivery of sediment and nutrient supplies to ocean basins, and in turn affecting terrestrial-marine feedbacks, which influence global climate (Fildani et al., 2016; Hessler et al., 2018). The responses of drainage systems to icehouse-to-greenhouse turnovers, however, are not well documented in the pre-Cenozoic geologic record (Blum and Törnqvist, 2000). To that end, we report here the first pre-Cenozoic record of basin-scale reorganization of the drainage across southwest Gondwana during the late Paleozoic ice age. This study documented major shifts in sediment sourcing in the mid- to high-latitude Paraná Basin in step with sequence boundaries, which can be correlated across southwest Gondwana (Griffis et al., 2019a). Our findings support the primary influence of continent-scale ice mass fluctuation on the mid- to high-latitude continental drainage system across this region of Gondwana.

We present the first high-resolution U-Pb zircon age control, obtained by chemical abrasion-isotope dilution-thermal ionization mass spectrometry (CA-ID-TIMS), for the glaciogenic deposits of the Kalahari Basin. U-Pb zircon ages by CA-ID-TIMS permit the calibration of closed-system, single crystals hosted within sedimentary successions at the $<0.1 \%$ level (cf. Gulbranson et al., 2010; Schmitz and Davydov, 2012; Griffis et al., 2018). High-resolution U-Pb CA-ID-TIMS ages are provided for two major deglaciation events across the Kalahari Basin: a major Carboniferous deglaciation and the final demise of the late Paleozoic ice age in the early Permian. The refined U-Pb zircon CA-ID-TIMS calibration for the Kalahari Basin allows for interbasinal correlation between the high-latitude Karoo Basin of southern Africa and the mid- to high-latitude Paraná Basin of Brazil. Detrital zircon U-Pb geochronology analysis of sediments in the downstream Paraná Basin, sampled across the refined U-Pb zircon CA-ID-TIMS framework, argues for multiple drainage reorganizations across the latest Carboniferous and earliest Permian, which are directly correlated with the Gondwanan glacial record.

\section{SOUTHWEST GONDWANA LATE PALEOZOIC RECORD}

The late Paleozoic ice age is Earth's penultimate glaciation and the only deep-time record of an icehouse-to-greenhouse transition in a world colonized by metazoan life and widespread tropical forests (Gastaldo et al., 1996). The demise of the late Paleozoic ice age was accompanied by major faunal and floral reorganization and changes in atmospheric chemistry, climate, and the hydrologic cycle (Montañez and Poulsen 2013; DiMichele, 2014; Richey et al., 2020). The sedimentary deposits of the Karoo, Kalahari, and Paraná Basins are among the highest-fidelity archives of the glaciation across southwestern Gondwana (Fig. 1; Visser, 1997; Rocha-Campos et al., 2008; Stollhofen et al., 2008). The correlation of glacial events and sequence boundaries across these basins is crucial for refining the autogenic and allogenic controls on the sedimentary fill. The temporal calibration of the stratigraphic record of southern Gondwana, built through high-resolution U-Pb zircon CA-ID-TIMS analysis of interglacial and postglacial deposits across SW Gondwana, reveals that major sequence boundaries, which are independently observed in the Paraná (cf. Holz et al., 2010) and Karoo Basins (cf. Visser, 1997), are temporally correlative at the <106 yr time scale (Griffis et al., 2018, 2019a). Importantly, the CA-ID-TIMS calibrated framework for SW Gondwana shows that Paraná Basin lowstands are correlative with ice buildup in the Karoo Basin, whereas ice minima or deglaciations across the Karoo Basin are correlative with major 
basin-scale transgressions in theParaná Basin (Griffis et al., 2019a). The U-Pb radioisotope-constrained stratigraphic record indicates that Paraná Basin was ice free by the latest Carboniferous, whereas the high-latitude Karoo Basin was glacially influenced through the late early Permian (282 Ma), confirming a latitudinal control on the glacial record (Isbell et al., 2012; Griffis et al., 2019a). Furthermore, this record suggests that Earth experienced a pronounced climate amelioration in the latest Carboniferous, as evidenced by the loss of ice in the Paraná and Kalahari Basins, followed by an acute cooling and the return of high-latitude ice in the Karoo Basin and possibly the Kalahari Basin at ca. $298 \mathrm{Ma}$, though highresolution age control from this interval is lacking across most of Gondwana (Stollhofen et al., 2008).

In this context, high-resolution U-Pb zircon CA-ID-TIMS geochronology for the Kalahari Basin of Namibia is crucial to test the interbasinal correlations across southwest Gondwana. The Kalahari Basin is also a key to evaluating the proposed geographic and climate controls on the inferred record of late Paleozoic continental ice, given its geographic location between the high-latitude Karoo Basin and the mid- to high-latitude Paraná Basin, its well documented glacial record, and the abundance of volcanic ash to date (Grill, 1997; Bangert et al., 1999; Bangert, 2000a; Stollhofen et al., 2008). Furthermore, the Kalahari region of southwest Africa was a key sediment source area for Paraná Basin sediments and was occupied by glacial and fluvial systems that shared connections to central and eastern Africa, ultimately enabling us to investigate correlations between the African glacial record and sedimentary provenance within the Paraná Basin (Visser, 1987, 1989; Griffis et al., 2019a, 2019b).

An African provenance for the glaciogenic deposits in the Paraná Basin is well documented (e.g., dos Santos et al., 1996; Vesely et al., 2015; Griffis et al., 2019b). In southwest Africa, incised glacial valleys, roche moutonnées, subglacial striations, and glacio-fluvial systems all show preferential paleoflow directions toward the Paraná Basin (Fig. 2A; Martin, 1981; Visser, 1987, 1997; Andrews et al., 2019). In the Paraná, subglacial bedrock incisions along the eastern margin of the basin and subglacial striated pavements show preferential NW-SE orientation and flow directions, which are congruent with an African ice center (Fallgatter and Paim, 2019; da Rosa et al., 2016; Valdez Buso et al., 2019). Detrital zircon analyses of Carboniferous glaciogenic deposits along the eastern margin of the Paraná record major shifts in provenance, which track changes in ice distribution and sourcing (Griffis et al., 2019b). In the Lower Carboniferous, the Paraná glaciogenic succession is enriched in local sources, whereas the sedimentary rocks from the Upper Carboniferous record reveal a strong African affinity (Griffis et al., 2019b). Additional large-scale shifts in sedimentary provenance have also been observed across basinscale sequence boundaries in the early Permian postglacial deposits of the Paraná Basin, though this sedimentary provenance record has not been investigated in the context of the Gondwanan ice and climate history (Canile et al., 2016). In the following section, we introduce the geologic setting and stratigraphy for the Paraná and Kalahari Basins.

\section{Paraná Basin}

The Paraná Basin is a large intracratonic basin with an areal extent of $1.7 \times 106 \mathrm{~km} 2$ across southern Brazil. Of that region, $1.0 \times 106 \mathrm{~km} 2$ are covered by late Paleozoic glaciogenic strata (Rocha-Campos et al., 2008). The Carboniferous and early Permian stratigraphy of the Paraná Basin is composed of a 1.3$\mathrm{km}$-thick succession of glaciogenic rocks (Itararé Group), which are overlain by 200-m-thick postglacial deposits (Guatá Group). In the southern Paraná Basin, Rio Grande do Sul State, Brazil, the glaciogenic record is limited to a single glacial-deglacial cycle, whereas northward and along the southeastern margin of the basin (Santa Catarina, Paraná, and Sao Paulo States), at least five glacial-deglacial cycles are recorded (Vesely et al., 2015). In Santa Catarina State, the focus of this study (\#1 in Fig. 1), the uppermost Itararé Group is locally divided into the Rio do Sul Formation, composed of organic-rich mudstone, sandstone, and diamictite, which are interpreted as deep-marine turbidite and glacially influenced mass-flow deposits (Fig. 1; Schemiko et al., 2019). The Rio Bonito Formation of the Guatá Group directly overlies the Itararé Group and is subdivided into the Triunfo, Paraguaçu, and Siderópolis Members (Fig. 2A; Holz et al., 2008). The Triunfo and Siderópolis Members are composed of coal and sandstones, which are interpreted to have been deposited in terrestrial and littoral environments. The Paraguaçu Member separates the Triunfo and Siderópolis Members and is composed of fine sandstones 
and mudstones, which are interpreted to have been deposited in an offshore, prodelta depositional environment (Holz et al., 2010). The Paraguaçu Member records the maximum transgression within the Rio Bonito Formation. The Rio do Sul and Rio Bonito Formations deepen to the west and show prevailing flow directions distributed from the north, south, and east, with proposed sources of sediment emanating from southwestern Africa (dos Santos et al., 1996; da Rosa et al., 2016; Schemiko et al., 2019). The plutonic and metamorphic basement rocks surrounding the eastern margin of the Paraná Basin, Santa Catarina State, were formed during the Pan-African orogeny. Crystallization ages of zircons from these deposits range between 900 and $550 \mathrm{Ma}$, with some Paleoproterozoic (2.1-1.8 Ma) inheritance (Fig. 2A; Basei et al., 2008, 2010; Rino et al., 2008).

\section{Kalahari Basin, Southern Africa (Aranos and Karasburg Basins)}

The Kalahari Basin occupies an area of $2.5 \times 106$ km2 across southern Africa (Visser, 1997; Cairncross, 2001). Glaciogenic rocks occur in outcrop and in core sampled across the extent of the basin. The glaciogenic rocks are hosted within the Dwyka Group, which attains a maximum thickness of $800 \mathrm{~m}$ in core and up to $200 \mathrm{~m}$ thickness in outcrop along the western escarpment of the basin in central and southern Namibia (Visser, 1997; Cairncross, 2001; Stollhofen et al., 2008). In this study, we focused on the southern Kalahari region, where the depositional basin has been subdivided into the Aranos and Karasburg Basins (\#2 in Fig. 1; Martin, 1981; Ziegler, 2019). In the Aranos and Karasburg Basins, the Dwyka Group lies unconformably on Cambrian and Precambrian basement, respectively. The lowermost Dwyka Group is composed of boulder beds, glacial-marine diamictites, and sandstones deposited in subglacial and ice-proximal environments (Visser, 1997; Werner, 2006). Thick organic-rich mudstones (20-30 m), referred to as the Ganigobis Shale in the Aranos Basin and the Zwartbas Shale in the Karasburg Basin, directly overlie the glaciogenic deposits of the lower Dwyka Group. These mudstones are marine in origin, based on the macrofossil and trace fossil assemblages, which include marine bivalves, radiolaria, and crinoids, and they are interpreted as representing a major transgression across the Kalahari and Karoo Basins (\#2 on Fig. 1; Visser, 1997; Bangert et al., 2000b; Scheffler et al., 2006; Stollhofen et al., 2008). Proglacial and ice-distal glaciogenic deposits of the upper Dwyka Group overlie the transgressive black shales (Visser, 1997; Werner, 2006; Stollhofen et al., 2008). In the Karasburg Basin, the organic-rich mudstones of the Prince Albert Formation, lower Ecca Group, overlie the Dwyka Group. In the Aranos Basin, the Dwyka Group is overlain by a complex assemblage of littoral sandstones and mudstones, which represent the marginal marine facies of the Prince Albert Formation. This sedimentary assemblage is referred to as the Nossob Formation (Miller, 2008). Visser (1997) described the overall transition from subglacial boulder beds or ice-proximal deposits to the overlying deep-water mudstones as four deglaciation sequences (DS I to DS IV) correlated across southern Africa. In situ U$\mathrm{Pb}$ zircon secondary ion mass spectrometry (SIMS) and laser ablation-inductively coupled plasma-mass spectrometry (LA-ICP-MS) analyses of volcanic ash deposits hosted within the Ganigobis and Zwartbas shales (DS II) and mudstones of the lowermost Prince Albert Formation (DS IV) of the Kalahari Basin broadly suggest a late Carboniferous through early Permian age for the glacial record (\#2 in Fig. 1; Bangert et al., 1999; Bangert, 2000; Stollhofen et al., 2008; Zieger et al., 2019, 2020).

Plutonic and metamorphic basement rocks, which surround the Kalahari region, formed during the Damara and Pan-African orogenic events, yielding zircon crystallization ages between 1300 and $550 \mathrm{Ma}$ and in the range 2.1-1.8 Ga (Fig. 2; Rino et al., 2008; Foster et al., 2015). Grenvillian-age (1100-1000 $\mathrm{Ma}$ ) zircons are common in the Namaqua Natal belt of southern Namibia (Eglington, 2006; Foster et al., 2015). Importantly, Mesoproterozoic-age basement is common across southern and eastern Africa, whereas basement rocks of this age are absent across the southeast margin of the Paraná Basin (Basei et al., 2008, 2010; Bingen et al., 2009; Linol et al., 2016; De Wit et al., 2020; Rino et al., 2008).

\section{SW GONDWANA GEOCHRONOLOGY}


In this section, we discuss existing in situ (SIMS and LA-ICP-MS) geochronologic age constraints for the late Paleozoic ice age glaciation in the Kalahari Basin and present new U-Pb zircon CA-ID-TIMS geochronologic age datafor the previously dated deposits. In addition, we present new detrital zircon geochronology from the Paraná Basin of Brazil that, when combined with the refined glaciogenic record of the Kalahari, allowed us to investigate the changes in sediment sourcing that occurred in step with changes in the SW Gondwana ice record. Details of sample preparation and analytical procedures along with the data tables, concordia plots, and outcrop photographs can be found in the Supplemental Material.1

\section{Existing U-Pb Zircon Geochronology for the Kalahari Basin}

The Carboniferous- and Permian-age deposits of the Kalahari Basin have a well-documented volcanic record (Grill, 1997). The Ganigobis and Zwartbas shales (DS II) and mudstones of the lowermost Prince Albert Formation (DS IV) of the Kalahari Basin are replete with volcanic ash, which have been the target of multiple U-Pb zircon dating efforts using in situ methods over the last two decades (Bangert et al., 1999; Bangert, 2000a, Werner, 2006; Stollhofen et al., 2008; Zieger et al., 2019, 2020). SIMS 206Pb/238U zircon weighted mean ages of $302 \pm 3.0 \mathrm{Ma}$ and $299.2 \pm 3.2 \mathrm{Ma}(1 \sigma)$ have been reported from two ashfall tuffs, sampled from the Ganigobis shale (DS II) in the Aranos subbasin (Bangert et al., 1999). A similar SIMS $206 \mathrm{~Pb} / 238 \mathrm{U}$ zircon weighted mean age of $302.3 \pm 2.1 \mathrm{Ma}(1 \sigma)$ was reported from the Zwartbas shale, suggesting the two deposits are isochronous (Bangert, 2000). Recently reported LAICP-MS U-Pb zircon ages of $296.0 \pm 2.4 \mathrm{Ma}$ and $296.2 \pm 2.3 \mathrm{Ma}(2 \sigma)$ from the Zwartbas and Ganigobis shales, respectively, suggest a slightly younger age for the deposits (Zieger et al., 2019, 2020). The final demise of the late Paleozoic ice age in this region of SW Gondwana is constrained by a SIMS 206Pb/238U zircon age of $290.9 \pm 1.9 \mathrm{Ma}(1 \sigma)$, which was sampled from an ash-fall tuff within the Owl Gorge Member of the Prince Albert Formation, $7 \mathrm{~m}$ above the Dwyka Group (Werner, 2006; Stollhofen et al., 2008). All reported in situ analyses from the Kalahari Basin are characterized by highly dispersed zircon populations, with dispersion in all samples exceeding 25 m.y. Zircon age dispersion is a common phenomenon, well documented in volcanic tuff and plutons. Age dispersion may be the result of prior zircon crystallization (i.e., formation of xenocrysts), open-system behavior (i.e., Pb-loss), and/or analytical error (Schoene, 2014; Griffis et al., 2018). The large individual analytical uncertainties of zircons measured using in situ techniques, which are on the order of $2 \%-5 \%(2-\sigma)$ for the Kalahari Basin data sets, are unable to resolve these aforementioned processes. Furthermore, the reported depositional ages likely average over multiple periods of zircon crystallization and may mask any open-system behavior or analytical error (cf. Griffis et al., 2018). As an example, the SIMS 206Pb/238U zircon age data set for the Owl Gorge Member reveals three distinct zircon population clusters, one at the reported age of $290.9 \mathrm{Ma}$, an older age of 297.8 Ma, and a young cluster at $280.7 \mathrm{Ma}$, all of which have acceptable mean square of weighted deviates (MSWD) values and comparable precision (cf. Griffis et al., 2018; Werner, 2006). Each of the alternative age interpretations is equally valid, though if $\mathrm{Pb}$ loss was pervasive, then the older ages would be more accurate, whereas if xenocryst zircons form a dominant population and $\mathrm{Pb}$-loss can be ruled out, then the youngest cluster could be interpreted as the age of the bed. In order to resolve this complexity, with the goal of refining intrabasinal correlations for the late Paleozoic ice age glaciation across the Kalahari Basin, we report new CA-ID-TIMS analyses from the same depositional sequences, and, in one case, the same layer (Owl Gorge Member) as the previously reported in situ analyses. CAID-TIMS analysis employs chemical treatments of the zircon prior to analysis to mitigate $\mathrm{Pb}$ loss (cf. Mattison, 2005) and provides temporal resolution at the $0.1 \%$ level $(2 \sigma)$, which is needed in order to resolve complex age distributions. In the following section we report new U-Pb data on closed-system zircons.

\section{Kalahari Basin U-Pb CA-ID-TIMS Zircon Geochronology}

Here, we report the first high-resolution U-Pb zircon CA-ID-TIMS age control for ash-fall tuffs located within the Aranos and Karasburg Basins of the greater Kalahari Basin, Namibia. Tuffs were sampled from organic-rich mudstones of the Ganigobis and Zwartbas shales of the Dwyka Group (DS II equivalent of Visser, 1997) and from the Owl Gorge Member of the Prince Albert Formation (DS IV of Stollhofen et al., 
2008). Zircon CA-ID-TIMS measurements were completed at the Berkeley Geochronology Center following the analytical procedures outlined in Griffis et al. (2018). Zircon age distributions in all samples are complex due to the presence of xenocrysts and spurious young grains, interpreted to record $\mathrm{Pb}$ loss (Fig. 3

). Thus, we report three separate $206 \mathrm{~Pb} / 238 \mathrm{U}$ age interpretations for each sample, which include a weighted mean of the youngest coherent group, a youngest detrital zircon algorithm age calculated in Isoplot, and a Bayesian model age (Griffis et al., 2019a; Keller et al., 2018). In all samples, the three reported ages overlap within analytical uncertainty at the 20level. We elected to use the calculated weighted mean ages for all samples, given the agreement of these ages across the basin and with the recently calibrated stratigraphic assignments for the Karoo and Paraná Basins.

\section{Aranos Basin}

Dwyka Group—Ganigobis Shale Member (GS. 1; locality $25^{\circ} 4921.00^{\prime} S, 18^{\circ} 031.50^{\prime}$ E). The Ganigobis Shale Member (Dwyka Group) manifests as cliff-forming black shales (up to $20 \mathrm{~m}$ thick), which can be found along the escarpment of the Fish River near the settlement of Ganigobis and the village of Tses (Bangert et al., 1999). Volcanic ash is abundant and occurs as thin beds $(<3 \mathrm{~cm})$. A distinct 2-cm-thick white volcanic ash layer was sampled $1.5 \mathrm{~km}$ north of the settlement of Ganigobis and $5 \mathrm{~m}$ above the base of the Ganigobis Shale Member. Zircons are abundant within the sampled volcanic ash, are euhedral, and show no evidence of transport. In total, 10 zircon grains were analyzed and produced ages between $305.69 \mathrm{Ma}$ and $298.80 \mathrm{Ma}$ (Fig. 3). The youngest detrital zircon algorithm produced an age of $298.77+0.61 /-0.78$, and we report a Bayesian model age of $298.88+0.62 /-0.81 \mathrm{Ma}$. A weighted mean age of $299.31 \pm 0.35 \mathrm{Ma}$ was calculated using the four youngest grains that overlapped at $2 \sigma$ uncertainty, and this is interpreted as the age of this deposit. The Th/U ratios were slightly elevated, relative to the global average value for zircon, and ranged between 0.9 and 1.6 (cf. Binedman et al., 2006).

\section{Karasburg Basin}

Dwyka Group-Zwartbas Shales (ZWFUN. 1 and ZWFUN.2; locality $28^{\circ} 411^{\prime} 10.40^{\prime} \mathrm{S}, 17^{\circ} 3335.20^{\prime}$ E). The Zwartbas shales (up to $20 \mathrm{~m}$ thick) outcrop along the northern embankment of the Orange River, $6 \mathrm{~km}$ west of the village of Noordoewer (Werner, 2006). Thin volcanic ash layers $(<5 \mathrm{~cm})$ are abundant throughout the shales (Grill, 1997). One sample (ZWFUN.1) was collected $5 \mathrm{~m}$ above the base of the black shales. In total, 19 zircon grains were analyzed and produced ages between $316.91 \mathrm{Ma}$ and 281.42 Ma. The three youngest grains in this analysis (294.48 Ma, 291.79 Ma, and 281.42 Ma) did not overlap and are interpreted as having experienced $\mathrm{Pb}$ loss and were therefore rejected from the age calculations. The youngest detrital zircon algorithm produced an age of $300.10+0.51 /-0.72 \mathrm{Ma}$, and we report aBayesian model age of $300.02+0.57 /-0.95 \mathrm{Ma}$. A weighted mean age of $300.45 \pm 0.37 \mathrm{Ma}$ was calculated from the three youngest reproducible grains that clustered at the $2 \sigma$ level, and this is interpreted as the age of this deposit (Fig. 3). The Th/U ratios ranged from 0.7 to 1.2 .

ZWFUN.2 was sampled $2 \mathrm{~m}$ above ZWFUN.1. In total, 14 zircon grains were analyzed and produced ages between 303.21 Ma and 299.16 Ma (Fig. 3). The youngest detrital zircon algorithm produced an age of $299.17+0.31 /-0.51 \mathrm{Ma}$, and we report a Bayesian model age of $299.26+0.36 /-0.41 \mathrm{Ma}$. A weighted mean age of $299.41 \pm 0.24 \mathrm{Ma}$ was calculated using the four youngest grains that overlapped at the $2 \sigma$ level, and this is interpreted as the age of this deposit. Th/U ratios ranged from 0.7 to 1.2 .

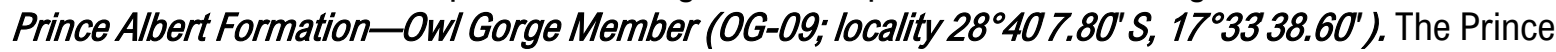
Albert Formation, composed of black shales and very fine-grained sandstones, directly overlies the glaciogenic deposits of the Dwyka Group and is interpreted to be nonglacial. The Prince Albert Formation is well exposed in canyons $6 \mathrm{~km}$ to the north and west of the village of Noordoewer, in the region referred to as the Owl Gorge (Werner, 2006). The Owl Gorge Member of the Prince Albert Formation presents one of the best exposures of the contact between the glaciogenic deposits of the Dwyka Group and the organic-rich shales of the lower Ecca Group. A volcanic ash layer $(<1 \mathrm{~cm})$ was sampled $7 \mathrm{~m}$ above the top of the Dwyka Group. This sample was obtained from the same depositional horizon as that dated in Werner (2006). In total, 23 zircon grains were analyzed. Three zircon grains produced early Paleozoic ages (481.80 Ma, 468.19, and $413.91 \mathrm{Ma}$ ), and we interpret the zircons as xenocrysts. The remaining 
20 zircon grains produced ages between $319.08 \mathrm{Ma}$ and $294.86 \mathrm{Ma}$. We interpret the youngest measured grain as having experienced $\mathrm{Pb}$ loss, which manifests as dispersion on the concordia and rank-order plots and results in the doubling of the MSWD value of the weighted average for this sample when included, and therefore, we rejected the youngest single grain from the age calculation (Fig. 3; Fig. S2). The youngest detrital zircon algorithm produced an age of $295.43+0.41 /-0.46 \mathrm{Ma}$, and we report a Bayesian model age of $295.45+0.4 /-0.59 \mathrm{Ma}$. A weighted mean age of $295.84 \pm 0.47 \mathrm{Ma}$ was calculated from the four youngest closed-system zircons that clustered at the $2 \sigma$ level, and this is interpreted as the age of this deposit (Fig. 3). Th/U ratios were slightly elevated and ranged from 0.9 to 2 .

\section{Paraná Basin U-Pb Detrital Zircon Analysis}

In this subsection, we present new U-Pb detrital zircon ages for four samples collected from a core (7-RL-04-SC; Fig. 1) that was retrieved outside the town of Anitápolis, Santa Catarina State, Brazil, and contains the Rio do Sul and Rio Bonito Formations. Core samples (5-10 cm long) were taken across key sequence boundaries. The sequence boundaries have been correlated across the Paraná Basin and constrained by high-resolution U-Pb zircon CA-ID-TIMS ages (Griffis et al., 2018., 2019a). In situ, detrital zircon U-Pb isotope measurements were made at the University of California-Davis. Zircons were ablated with a $193 \mathrm{~nm}$ excimer laser (Photon Machines Analyte 193H), and the resulting aerosolized particles were transferred to a Thermo Element XR high-resolution ICP-MS. Details on the analytical procedures and sample reduction can be found in the Supplemental Material. All samples were corrected for common $\mathrm{Pb}$ using the Andersen Excel macros (Andersen, 2002). Zircons were filtered for concordance, and zircons were rejected if they yielded ages younger than $1000 \mathrm{Ma}$ that fell off the concordia ( $2 \sigma$ level) or ages older than $1000 \mathrm{Ma}$ and $>20 \%$ discordant (cf. Spencer et al., 2016). In total, 596 zircons from four samples were analyzed across core 7-RL-04-SC, of which 358 were used to constrain sedimentary provenance. Furthermore, our analysis complements a large $(n>1000)$ published $\mathrm{U}-\mathrm{Pb}$ zircon study from the White Stratigraphic Column in Santa Catarina State, Brazil (Canile et al., 2016). The White Column is located $65 \mathrm{~km}$ to the south of the town of Anitápolis, where core 7-RL-04-SC was retrieved, and is the best outcrop exposure of the Rio do Sul and Rio Bonito Formations (Fig. 2A). Canile et al. (2016) reported a total of eight samples from the Rio do Sul through Rio Bonito Formations. Here, we include seven of the eight samples from the Rio do Sul Formation $(n=1)$, Triunfo Member $(n=2)$, Paraguaçu Member $(n$ $=2$ ), and Siderópolis Member $(n=2)$ (Fig. 1). One sample from the Rio do Sul Formation was rejected due to a limited number of zircons analyzed $(n=49)$ that fit the aforementioned acceptance criteria. All of the samples from Canile et al. (2016) were filtered using the aforementioned criteria, with a total of 754 zircons included in our analysis. Combined, our study presents over 1111 zircons in the context of the refined stratigraphic framework for southern Gondwana (Griffis et al., 2019a). The results are presented using kernel density estimates (KDE) determined in the $\mathrm{R}$ statistical package Provenance (Vermeesch et al., 2016). Statistical comparisons between samples were employed using the likeness metric, a two-sample Kolmogorov-Smirnov (K-S) test, and multidimensional scaling (Satkoski et al., 2013; Vermeesch et al., 2016). Likeness values $>0.60$ were considered statistically significant. The twosample K-S test was used to test the null hypothesis that two samples were derived from the same population ( $95 \%$ confidence level, $p$ values $>0.05$ ). A summary of the statics is presented in Table 1 , with statistically significant values highlighted.

\section{Results by Sample for Core 7-RL-04-SC}

ANT 66 (Rio do Sul Formation). A mud-rich fine sandstone was sampled from the glacially influenced Rio do Sul Formation, $66 \mathrm{~m}$ above the base of the core (Fig. 1). In total, 129 zircons were analyzed, of which 73 were included in our analysis, with the remainder rejected as they fell short of the quality criteria. KDEs revealed major peaks at $540 \mathrm{Ma}, 1000 \mathrm{Ma}$, and $1860 \mathrm{Ma}$. Accessory peak occurred at $1370 \mathrm{Ma}, 1560 \mathrm{Ma}$, and $2000 \mathrm{Ma}$ (Fig. 2B).

ANT 113 (Triunfo Member). A fine-grained fluvial sandstone was sampled from the lowermost Triunfo Member of the Rio Bonito Formation, $113.3 \mathrm{~m}$ above the base of the core and directly above the SB-2 contact. In total, 185 grains were analyzed, of which 104 were included in our analysis. This sample 
showed a strong unimodal population at $520 \mathrm{Ma}$ as determined by the KDE. Accessory peaks occurred at $1040 \mathrm{Ma}$ and $1860 \mathrm{Ma}$ (Fig. 2B).

ANT 222 (Siderópolis Member). A medium-grained fluvial sandstone was sampled from the Siderópolis Member, $222 \mathrm{~m}$ above the base of the core and $4 \mathrm{~m}$ above the SB-3 contact. In total, 120 grains were analyzed, and 80 were included in our analysis. The KDE revealed major peaks at $580 \mathrm{Ma}, 1920 \mathrm{Ma}$, and $2010 \mathrm{Ma}$. Accessory peaks occurred at $1150 \mathrm{Ma}$ and $2400 \mathrm{Ma}$ (Fig. 2B).

ANT 290 (Siderópolis Member). A fine-grained fluvial sandstone sample was sampled from the upper Siderópolis Member, $290 \mathrm{~m}$ above the base of the core and $73 \mathrm{~m}$ above SB-3. KDEs revealed major peaks at $530 \mathrm{Ma}, 1030 \mathrm{Ma}, 1890 \mathrm{Ma}$, and $2000 \mathrm{Ma}$. Accessory peaks occurred at $280 \mathrm{Ma}$ and $2750 \mathrm{Ma}$ (Fig. 2B).

\section{RECONSTRUCTION OF PALEO-ICE EXTENT AND DRAINAGE ACROSS SW GONDWANA}

The new high-resolution U-Pb zircon CA-ID-TIMS age control for the Aranos and Karasburg Basins refines the late Paleozoic glacial record for southwest Gondwana. The reported depositional ages for the Ganigobis and Zwartbas shales range between $300.45 \pm 0.37 \mathrm{Ma}$ (ZWFUN.1) and 299.31 $\pm 0.35 \mathrm{Ma}$ (GS.1), confirming a previously documented (for the Parana Basin) synchronous and widespread deglaciation event across this region in the latest Carboniferous (Griffis et al., 2019a, 2019b). Importantly, the age control from these shales is from volcanic ash deposits, which occur 5-10 m above subglacial deposits, therefore providing upper age constraints on the final demise of grounded ice in southwestern Africa. Furthermore, marine invertebrate faunas in the black shales indicate a marine origin and record a major transgressive event in the latest Carboniferous following the loss of ice (Stollhofen et al., 2008; Miller, 2008; Griffis et al., 2019a).

A time-equivalent transgressive deposit, the Rio do Sul Formation, occurs in the neighboring Paraná Basin (\#1 in Fig. 1; Fig. 4; Schemiko et al., 2019). The late Carboniferous Rio do Sul Formation marks the final demise of glacial influence in the Paraná Basin. The detrital zircon U-Pb geochronology for the Rio do Sul Formation, however, is complex. The major U-Pb age peaks identified by the KDEs are consistent with local bedrock ages of the Ribeira belt (650-500 Ma), though the U-Pb ages alsohave an African affinity (600-500 Ma and 1100-1000 Ma; Fig. 2B; see Basei et al., 2008, 2010; Foster et al., 2015). Importantly, the 1100- 1000 Ma zircons have no local South American provenance within this region of the Paraná Basin. This component of zircon ages is, however, common across southern Africa basement rocks, including the Damara belt and basement rocks further east associated with the Congo and Tanzania cratons. All of these source regions were located to the east of the Paraná Basin during the Carboniferous (Fig. 2A; Foster et al., 2015; Linol et al., 2016; Thomas et al., 2016; Ziegler et al., 2019; Griffis et al., 2019a, 2019b). Glacially incised valleys and striated pavements across Namibia as well as fluvial systems across southern Africa all indicate westward paleoflow across southern Africa and toward the Paraná Basin, thus confirming an African source for the glaciogenic deposits of the Rio do Sul Formation (Figs. 2A and 5; Martin, 1981; Visser, 1987 1989; Bicca et al., 2017; Andrews et al., 2019; Le Heron et al., 2019).

Glacially influenced mass transport deposits directly overlie the Ganigobis and Zwartbas shales of the Aranos and Karasburg Basins, signaling a return to icehouse conditions in this region in the earliest Permian. Glacially influenced deposits, equivalent to lower DS III in South Africa, reach a maximum thickness of $100 \mathrm{~m}$ and are interpreted to have been sourced from glaciers on the southern African continent (Visser, 1997; Miller, 2008). In the neighboring Paraná Basin, the fluvial/delta-top deposits of the lower Triunfo Member are juxtaposed on deeper-water delta-front deposits of the Rio do Sul Formation. The Triunfo Member has been interpreted to indicate a major base-level drop at $>298 \mathrm{Ma}$, which is temporally correlative with the return of glacial deposits in southern Africa (Fig. 5; Griffis et al., 2019a). The earliest Permian lowstand deposits of the Triunfo Formation unconformably overlie the Rio do Sul Formation and are marked by a sharp shift in sedimentary style and provenance in the Paraná Basin. Detrital zircons from these fluvial deposits indicate a unimodal Cambrian age (530-520 Ma) population. The local Ribeira belt, which surrounds the sample locality to the east, is the most likely sediment source for these zircons (Fig. 2; Basei et al., 2008). 
The demise of the late Paleozoic glacial record in Namibia is constrained by a new high-resolution U-Pb zircon age of $295.84 \pm 0.47 \mathrm{Ma}$ (OG-09) for a thin volcanic ash layer in the Owl Gorge Member of the Prince Albert Formation. Given that this ash is $\sim 7 \mathrm{~m}$ from the contact with the underlying glacial deposits of the Dwyka Group, this age is proximal to the collapse of glaciation in this region. Importantly, the age for the Owl Gorge Member is congruent with that for DS III in South Africa $(296.41+0.27 /-0.35 \mathrm{Ma}$; Griffis et al., 2019a), indicating the synchronous loss of ice across southern Africa in the early Permian. This synchronous loss of ice across southern Africa is also contemporaneous with the marine mudstones and sandstones of the Paraguaçu Member (Rio Bonito Formation) in the Paraná Basin, previously interpreted as the maximum flood surface of a transgressive system recorded by the upper Triunfo and Paraguaçu Members (Griffis et al., 2019a). The detrital zircon record for the upper Triunfo and Paraguaçu Members reveals a complex distribution of U-Pb ages, with major peaks of Cambrian (550-520 Ma), Mesoproterozoic (1100-1000 Ma), and Paleoproterozoic (2060-1860 Ma) ages. Importantly, the upper Triunfo and Paraguaçu Members share a statistically significant population of ages similar to those from the Rio do Sul Formation (Figs. 2B, 4, and 5), including a significant amount of 1100-1000 Ma zircons. We interpret this pattern as a renewed input of African-sourced sediments into the Paraná Basin (Fig. 4; Canile et al., 2016).

A return to glaciogenic conditions occurred in the high-latitude Karoo Basin in the late early Permian, associated with the onset of DS IV (Fig. 4; Visser, 1997; Griffis et al., 2019a). At the same time, in the Paraná Basin, the return of high-latitude ice manifested as a forced regression, recognized by the juxtaposition of fluvial and littoral sandstones of the lower Siderópolis Member (Rio Bonito Formation) on top of prodelta and offshore deposits of the Paraguaçu Member (Griffis et al., 2019a). The lower Siderópolis Member contains a bimodal zircon population dominated by Cambrian ( $520 \mathrm{Ma}$ ) and Paleoproterozoic (2100-1800 Ma) age grains. As with the detrital zircon population of the lower Triunfo Member, the detrital zircon ages of the lower Siderópolis zircons are consistent with a Ribeira belt source (Fig. 2A; Basei et al., 2008). Furthermore, the lack of Mesoproterozoic zircons (1100-1000 Ma) confirms a restriction of African-sourced sediments into the Paraná Basin.

The overlying sandstones and mudstones of the upper Siderópolis Member mark the onset of a late early Permian transgression, which culminated with the deposition of the Palermo Formation and was coincident with the final demise of ice in SW Gondwana (Griffis et al., 2019a). The detrital zircon population within the upper Siderópolis deposits is also complex and defined by Carboniferous-Permian (300-280 Ma), Cambrian (560-530 Ma), Mesoproterozoic (1040-1030 Ma), and Paleoproterozoic (2010$1860 \mathrm{Ma}$ ) age peaks (Fig. 2B). The Carboniferous-Permian age peaks have been previously interpreted as sourced from the reworked explosive volcaniclastic deposits of the Choiyoi Province in Argentina (Rocha-Campos et al., 2011; Canile et al., 2016). As previously suggested, we interpret the source of the Cambrian-age zircons and Paleoproterozoic zircons as the Ribeira belt (Fig. 2A). In contrast, a southern African source is indicated by the Mesoproterozoic- and some Cambrian- and Paleoproterozoic-age grains, therefore indicating renewed African input into the Paraná Basin (cf. Foster et al., 2015; Zeiger et al., 2019). The data presented in this study for glaciogenic deposits in the Kalahari Basin, Namibia, and contemporaneous downstream fluvial and marine deposits in the Paraná Basin, Brazil, reveal a temporal pattern in sediment sourcing across the late Paleozoic of SW Gondwana. The detrital zircon U-Pb populations of transgressive deposits (i.e., the Rio do Sul Formation, Itararé Group, and the upper Triunfo, Paraguaçu, and upper Siderópolis Members, Rio Bonito Formation) include zircons sourced from both southeastern South America and southern Africa. In contrast, the detrital zircon spectra of the lowstand deposits in the early Permian succession of the Paraná Basin (lowermost Triunfo and Siderópolis Members) are dominated by locally sourced zircons indicating a restriction of African sediments into the Paraná Basin. Notably, these lowstand deposits correlate to the timing of expansion of glaciers across southern Africa (Griffis et al., 2019a, 2019b; this study). These observations were confirmed through likeness, K-S, and multidimensional scaling tests, with statistically significant correlations between detrital zircon samples from the transgressive deposits (Figs. 4 and 5; Table 1). Conversely, detrital zircons from the lowstand deposits have distinct distributions and share little statistical correlation with samples from the transgressive deposits (Table 1; Fig. 5). 


\section{SW Gondwana Drainage and Implications for Paleoclimate Feedbacks}

The geochronologic constraints on the high-latitude ice record of Namibia and the downstream changes in sediment delivery to the Paraná Basin presented in this study highlight both the dynamic nature of the late Paleozoic glaciogenic record and a climate influence on sedimentary routing and catchments across SW Gondwana. Together, the distributions of detrital zircon and high-precision U-Pb zircon CA-ID-TIMS ages permit us to reconstruct the temporal relationship between the timing of expansion and retraction of glaciers across southern Africa and periods of decreased and increased transport of southern African sediments to the Paraná Basin, Brazil (Fig. 6). Specifically, the onset of glacial conditions in SW Gondwana during the early Permian (ca. $298 \mathrm{Ma}$ and ca. $295 \mathrm{Ma}$ ) coincided with the restriction of African sediments into the Paraná Basin, with the zircon population reflecting a local Paraná bedrock source. Relatively short-lived (<1-2 m.y.) deglacial periods in the latest Carboniferous (300-299 Ma) and early Permian (296 Ma) across southern Africa and the terminal loss of glaciogenic deposits in South Africa in the latest early Permian (282 Ma) were all associated with the expansion of the Paraná Basin catchment and the routing of far-field African-sourced sediments into the basin (Fig. 6). Our observations are broadly consistent with Cenozoic detrital zircon records, which show large-scale changes in sediment sourcing and catchments linked to periods of ice expansion and retraction (cf. Fildani et al., 2016; Hessler et al., 2018) and changing climate (Goddard and Carrapa, 2018).

The aforementioned major shifts in sediment routing occur across sequence boundaries within the Paraná Basin, which have been correlated across SW Gondwana at the $106 \mathrm{yr}$ time scale. This has profound implications for the climate and associated climate feedbacks (Griffis et al., 2019a). Highlatitude fluvial systems have an outsized influence on the salinity, temperature, and nutrient flux in the modern global ocean, ultimately affecting global biogeochemical cycling and ocean chemistry (Holmes et al., 2012; Piliouras and Rowland, 2020). The documented late Carboniferous through early Permian changes in sediment routing and catchments would have greatly affected the delivery of freshwater and nutrients to ocean basins across SW Gondwana. We posit that freshwater and nutrient delivery would have been greatest during the deglaciation and ice-minima periods of the late Paleozoic ice age, when the catchment size was at its maximum extent. Climate simulations made using a fully coupled earth system model of southwest Gondwana are in agreement with this position, as this region was highly sensitive to climate forcing, with interglacial periods associated with precipitation values increasing 2- to 4-fold across glacial $(500 \mathrm{~mm})$ and into postglacial $(<2000 \mathrm{~mm})$ conditions in this region of Gondwana (Heavens et al., 2015). RECORD FOR SW GONDWANA

The high-resolution U-Pb zircon calibrated stratigraphic framework for the late Paleozoic glacial record of the Kalahari Basin reveals that all evidence of subglacial deposits within the basin is restricted to the Carboniferous. Our findings from the Kalahari Basin, in conjunction with recently published work from the Paraná (Brazil) and Karoo (South Africa) Basins, thus indicate that late Paleozoic glaciation across much of SW Gondwana was restricted to the Carboniferous (Fig. 4; Griffis et al., 2018, 2019a). Cooler periods occurred through the early Permian (prior to $298 \mathrm{Ma}$ and $295 \mathrm{Ma}$ ), separated by pronounced periods of deglaciation in the latest Carboniferous (ca. 300-299 Ma) and the early Permian (296 Ma), and terminal deglaciation in this overall region in the latest early Permian (ca. $282 \mathrm{Ma}$; Griffis et al., 2019a). Importantly, the new age constraints for the Kalahari Basin indicate that the previous stratigraphic assignments for southern Africa, which suggested that final deglaciation of the Karoo and Kalahari was contemporaneous, need to be revisited, given that the age for the lower Prince Albert Formation in South Africa is 12 m.y. older than the Owl Gorge Member of the Prince Albert Formation in the Kalahari Basin (Visser, 1997; Stollhofen et al., 2008; Griffis et al., 2019a, 2019b).

These results for three basins in southwest Gondwana highlight the dynamic nature of the late Paleozoic ice age. The presence of regionally correlated discrete deglaciations, which occurred on the 1-2 m.y. time scale, that were separated by discrete intervals of ice expansion reflects the sensitivity of the paleoglaciers to climate forcing. Moreover, the previously reconstructed U-Pb-calibrated glacial record is tightly coupled with long-term paleo- $\mathrm{CO}_{2}$ estimates (Griffis et al., 2019a, 2019b; Richey et al., 
2020). These findings do not support a protracted deglaciation model driven by the tectonic drift of Gondwana away from the equator or one driven by orogenic collapse (Isbell et al., 2012; Limarino et al., 2014), as these processes, which operate on longer time scales (106-108 yr), are incompatible with the occurrence of the inferred deglaciations across SW Gondwana, which occurred on the $<106 \mathrm{yr}$ time scale (Griffis et al., 2019a). Although we propose a climatically driven glaciation history for SW Gondwana, given the widespread synchroneity between the timing of glacial expansion and retraction across this region of southern Gondwana, we also acknowledge that the geographic position of SW Gondwana and the high-elevation areas would have created favorable boundary conditions for ice nucleation at this time.

\section{CONCLUSIONS}

The latest Carboniferous and early Permian successions of SW Gondwana host a highly dynamic glacial record-one characterized by multiple periods of glaciation that were separated by discrete deglaciation events. The presented high-resolution U-Pb zircon CA-ID-TIMS age control for the glaciogenic record in the Kalahari Basin, in conjunction with previously published U-Pb zircon data for the Paraná and Karoo Basins, confirms the hypothesis that deglacial (transgressive) and glacial (lowstand) events across SW Gondwana were temporally correlative. Subglacial evidence within the Kalahari Basin is restricted to the Carboniferous, with evidence of glaciation persisting into the early Permian in this region. The refined U$\mathrm{Pb}$ zircon CA-TIMS age control for the glaciogenic record of SW Gondwana reveals a 12 m.y. diachroneity between the Prince Albert Formation in the Kalahari and Karoo Basins, a formation once thought to be isochronous across region, which indicates that the interbasinal-scale correlations across the late Paleozoic section of southern Africa need to be revisited.

The late Carboniferous and early Permian U-Pb detrital zircon record from the Paraná Basin of Brazil tracks the high-latitude Gondwana ice record. Transgressive deposits within the Paraná Basin are associated with an influx of African-sourced sediment in the latest Carboniferous (300-299 Ma) and early Permian (296 Ma) and interpreted as an expansion of the basin catchment area. The return of ice in SW Africa in the earliest Permian (298 Ma and $295 \mathrm{Ma}$ ) is associated with lowstand fluvial and coal deposits in the Paraná Basin and a restriction of African-sourced sediments into the basin. The documented shifts in sediment routing across southwest Gondwana present opportunities to investigate climate feedbacks associated with changes in freshwater and nutrient delivery to high-latitude late Paleozoic ocean basins.

\section{ACKNOWLEDGMENTS}

We thank Nelson Mandela University for field assistance in Namibia. This manuscript greatly benefited from two anonymous referees and feedback from the associate editor, Alan Rooney. This study was funded by U.S. National Science Foundation awards EAR- 1729882 to Montañez and Yin, and EAR1728705 to Mundil, and National Aeronautics and Space Administration (NASA) grant 80NSSC17K0242 to Yin. Fernando Vesely and Roberto lannuzzi thank the Brazilian National Council for Scientific and Technological Development (CNPq) for the financial support (grants 461650/2014-2 and PQ 302842/2017-9, and 430096/2016-0 and PQ 312747/2017-9, respectively), and the Coordination for the Improvement of Higher Education Personnel (CAPES) Foundation for providing a graduate scholarship to Thammy Mottin. Last, we thank the Ann and Gordon Getty Foundation for supporting sample analysis at the Berkeley Geochronology Center.

\section{REFERENCES CITED}

Andersen, T., 2002, Correction of common lead in U-Pb analyses that do not report ${ }^{204} \mathrm{~Pb}$ : Chemical Geology, v. 192 , p. $59-79$, https://doi .org/10.1016/ S00092541(02)00195-X.

Andrews, G.D., McGrady, A.T., Brown, S.R., and Maynard, S.M., 2019, First description of subglacial megalineations from the late Paleozoic ice age in southern Africa: PLoS One, v. 14, no. 1, p. e0210673, https:// doi .org/10.1371/journal.pone.0210673.

Bangert, B., 2000, Tephrostratigraphy, Petrography, Geochemistry, Age and Fossil Record of the Ganigobis Shale Member and Associated Glaciomarine Deposits of the Dwyka Group, Late Carboniferous, Southern Africa [Ph.D. dissertation]: Würzburg, Germany, University of Würzburg, 260 p., http://opus.bibliothek.uniwuerzburg.de/opus/volltexte/2002/223/.

Bangert, B., Stollhofen, H., Lorenz, V., and Armstrong, R., 1999, The geochronology and significance of ash-fall tuffs in the glaciogenic Carboniferous-Permian Dwyka Group of Namibia and South Africa: Journal of African Earth Sciences, v. 29, p. 33-49, https://doi .org/10.1016/S0899-5362(99)00078-0.

Bangert, B., Stollhofen, H., Geiger, M., and Lorenz, V., 2000, Fossil record and high-resolution tephrostratigraphy of Carboniferous glaciomarine mudstones, Dwyka Group, southern Namibia: Geological Survey of Namibia Communications, v. 12, p. 235-245. 
Basei, M.A.S., Frimmel, H.E., Nutman, A.P., and Preciozzi, F., 2008, West Gondwana amalgamation based on detrital zircon ages from Neoproterozoic Ribeira and Dom Feliciano belts of South America and comparison with coeval sequences from SW Africa, in Pankhurst, R.J., et al., eds., West Gondwana: Pre-Cenozoic Correlations Across the South Atlantic Region: Geological Society [London] Special Publication 294, p. 239-256, https:// doi .org/10.1144/SP294.13.

Basei, M.A.S., Neves, B.B.B., Siga, O., Babinski, M., Pimentel, M.M., Gaeta Tassinari, C.C., Hollanda, M.H.B., Nutman, A., and Cordani, U.G., 2010, Contribution of SHRIMP U-Pb zircon geochronology to unravelling the evolution of Brazilian Neoproterozoic fold belts: Precambrian Research, v. 183, p. 112-144, https://doi .org/10.1016/ j.precamres.2010.07.015

Begg, G.C., Griffin, W.L., Natapov, L.M., O'Reilly, S.Y., Grand, S.P., O'Neill, C.J., Hronsky, J.M.A., Djomani, Y.P., Swain, C.J., Deen, T., and Bowden, P., 2009, The lithospheric architecture of Africa: Seismic tomography, mantle petrology, and tectonic evolution: Geosphere, v. 5, p. 23-50, https://doi .org/10.1130/GES00179.1

Bicca, M.M., Philipp, R.P., Jelinek, A.R., Ketzer, J.M.M., dos Santos Scherer, C.M., Jamal, D.L., and dos Reis, A.D., 2017, Permian-Early Triassic tectonics and stratigraphy of the Karoo Supergroup in northwestern Mozambique: Journal of African Earth Sciences, v. 130, p. 8-27, https://doi .org/10.1016/ j.jafrearsci.2017.03.003

Bindeman, I.N., Schmitt, A.K., and Valley, J.W., 2006, U-Pb zircon geochronology of silicic tuffs from the Timber Mountain/Oasis Valley caldera complex, Nevada: Rapid generation of large volume magmas by shallow-level remelting: Contributions to Mineralogy and Petrology, v. 152, no. 6, p. 649-665, https://doi .org/10.1007/ s00410-006-0124-1.

Bingen, B., Jacobs, J., Viola, G., Henderson, I.H.C., Skår, Ø., Boyd, R., Thomas, R.J., Solli, A., Key, R.M., and Daudi, E.X.F., 2009, Geochronology of the Precambrian crust in the Mozambique belt in NE Mozambique, and implications for Gondwana assembly: Precambrian Research, v. 170, p. 231-255, https://doi .org/10.1016/ j.precamres.2009.01.005

Blum, M.D., and Törnqvist, T.E., 2000, Fluvial responses to climate and sea-level change: A review and look forward: Sedimentology, v. 47, p. 2-48, https://doi .org/10.1046/ j.1365-3091.2000.00008.x.

Cairncross, B., 2001, An overview of the Permian (Karoo) coal deposits of southern Africa: Journal of African Earth Sciences, v. 33, p. 529-562, https://doi org/10.1016/S0899-5362(01)00088-4.

Canile, F.M., Babinski, M., and Rocha-Campos, A.C., 2016, Evolution of the Carboniferous-Early Cretaceous units of Paraná Basin from provenance studies based on U-Pb, $\mathrm{Hf}$ and $\mathrm{O}$ isotopes from detrital zircons: Gondwana Research, v. 40, p. 142-169, https://doi .org/10.1016/ j.gr.2016.08.008.

da Rosa, E.L.M., Vesely, F.F., and França, A.B., 2016, A review on late Paleozoic ice-related erosional landforms in the Paraná Basin: Origin and paleogeographical implications: Brazilian Journal of Geology, v. 46, no. 2, p. 147-166, https://doi .org/10.1590/2317- 4889201620160050.

De Wit, M., Linol, B., and Nengovhela, V., 2020, Proterozoic-Paleozoic sedimentary rocks and Mesozoic- Cenozoic landscapes of the Cape Mountains across the Kango Complex reveal 'more gaps than record' from Rodinia and Gondwana to Africa: Geoscience Canada, v. 47, p. 7-58, https://doi .org/10.12789/geocanj.2020.47.157.

DiMichele, W.A., 2014, Wetland-dryland vegetational dynamics in the Pennsylvanian ice age tropics: International Journal of Plant Sciences, v. 175, p. 123-164, https://doi .org/10.1086/675235.

Domeier, M., and Torsvik, T.H., 2014, Plate tectonics in the late Paleozoic: Geoscience Frontiers, v. 5, p. 303-350, https://doi .org/10.1016/ j.gsf.2014.01.002.

dos Santos, P.R., Rocha-Campos, A.C., and Canuto, J.R., 1996, Patterns of late Palaeozoic deglaciation in the Parana Basin, Brazil: Palaeogeography, Palaeoclimatology, Palaeoecology, v. 125, p. 165-184, https://doi .org/10.1016/S0031-0182(96)00029-6.

Dowdeswell, J.A., Ottesen, D., and Rise, L., 2010, Rates of sediment delivery from the Fennoscandian ice sheet through an ice age: Geology, v. 38, p. 3-6, https://doi .org/10.1130/G25523.1.

Eglington, B.M., 2006, Evolution of the Namaqua-Natal belt, southern Africa-A geochronological and isotope geochemical review: Journal of African Earth Sciences, v. 46, p. 93-111, https://doi .org/10.1016/ j.jafrearsci.2006.01.014.

Fallgatter, C., and Paim, P.S.G., 2019, On the origin of the Itararé Group basal nonconformity and its implications for the late Paleozoic glaciation in the Paraná Basin, Brazil: Palaeogeography, Palaeoclimatology, Palaeoecology, v. 531, p. 108225, https://doi .org/10.1016/ j.palaeo.2017.02.039.

Fildani, A., McKay, M.P., Stockli, D., Clark, J., Dykstra, M.L., Stockli, L., and Hessler, A.M., 2016, The ancestral Mississippi drainage archived in the late Wisconsin Mississippi deep-sea fan: Geology, v. 44, p. 479-482, https://doi .org/10.1130/G37657.1.

Foster, D.A., Goscombe, B.D., Newstead, B., Mapani, B., Mueller, P.A., Gregory, L.C., and Muvangua, E., 2015, U-Pb age and Lu-Hf isotopic data of detrital zircons from the Neoproterozoic Damara Sequence: Implications for Congo and Kalahari before Gondwana: Gondwana Research, v. 28, no. 1, p. 179-190, https:// doi .org/10.1016/ j.gr.2014.04.011.

Gastaldo, R.A., DiMichele, W.A., and Pfefferkorn, H.W., 1996, Out of the icehouse into the greenhouse: A late Paleozoic analog for modern global vegetational change: GSA Today, v. 6 , no. 10 , p. $1-7$.

Goddard, A.S., and Carrapa, B., 2018, Effects of Miocene-Pliocene global climate changes on continental sedimentation: A case study from the southern Central Andes: Geology, v. 46, p. 647-650, https://doi .org/10.1130/G40280.1.

Griffis, N.P., Mundil, R., Montañez, I.P., Isbell, J., Fedorchuk, N., Vesely, F., lannuzzi, R., and Yin, Q.Z., 2018, A new stratigraphic framework built on U-Pb single zircon TIMS ages and implications for the timing of the penultimate icehouse (Paraná Basin, Brazil): Geological Society of America Bulletin, v. 130, p. 848-858, https://doi .org/10.1130/B31775.1.

Griffis, N.P., Montanez, I.P., Mundil, R., Richey, J., Isbell, J., Fedorchuk, N., Linol, B., lannuzzi, R., Vesely, F., Mottin, T., da Rosa, E., Keller, B., and Yin, Q.Z., 2019a, Coupled stratigraphic and U-Pb zircon age constraints on the late Paleozoic icehouse-to-greenhouse turnover in south-central Gondwana: Geology, v. 47, no. 12, p. 1146-1150, https://doi .org/10.1130/G46740.1.

Griffis, N.P., Montañez, I.P., Fedorchuk, N., Isbell, J., Mundil, R., Vesely, F., Weinshultz, L., lannuzzi, R., Gulbranson, E., Taboada, A., Pagani, A., Sanborn, M.E., Huyskens, M., Wimpenny, J., Linol, B., and Yin, Q.Z., 2019b, Isotopes to ice: Constraining provenance of glacial deposits and ice centers in west-central Gondwana: Palaeogeography, Palaeoclimatology, Palaeoecology, v. 531, p. 108745, https://doi .org/10.1016/ j.palaeo.2018.04.020.

Grill, H., 1997, The Permo-Carboniferous glacial to marine Karoo record in southern Namibia: Sedimentary facies and sequence stratigraphy: Beringeria, v. 19, p. $1-98$.

Gulbranson, E.L., Montañez, I.P., Schmitz, M.D., Limarino, C.O., Isbell, J.L., Marenssi, S.A., and Crowley, J.L., 2010, High-precision U-Pb calibration of Carboniferous glaciation and climate history, Paganzo Group, NW Argentina: Geological Society of America Bulletin, v. 122, p. 1480-1498, https://doi .org/10.1130/ B30025.1.

Heavens, N.G. Mahowald, N.M., Soreghan, G.S., Soreghan, M.J., and Shields, C.A., 2015, A model-based evaluation of tropical climate in Pangaea during the late Palaeozoic icehouse: Palaeogeography, Palaeoclimatology, Palaeoecology, v. 425, p. 109-127, https://doi .org/10.1016/ j.palaeo.2015.02.024.

Hessler, A.M., Zhang, J., Covault, J., and Ambrose, W., 2018, Continental weathering coupled to Paleogene climate changes in North America: Geology, v. 46, p. 995-998, https://doi .org/10.1130/G45528.1.

Holmes, R.M., McClelland, J.W., Peterson, B.J., Tank, S.E., Bulygina, E., Eglinton, T.I., Gordeev, V.V., Gurtovaya, T.Y., Raymond, P.A., Repeta, D.J., Staples, R. Striegl, R.G., Zhulidov, A.V., and Zimov, S.A., 2012, Seasonal and annual fluxes of nutrients and organic matter from large rivers to the Arctic Ocean and surrounding seas: Estuaries and Coasts, v. 35, p. 369-382, https://doi .org/10.1007/s12237-011-9386-6.

Holz, M., Souza, P.A., and lannuzzi, R., 2008, Sequence stratigraphy and biostratigraphy of the late Carboniferous to early Permian glacial succession (Itarare subgroup) at the eastern-southeastern margin of the Parana Basin, Brazil, in Fielding, C.R., Frank, T.D., and Isbell, J.L., eds., Resolving the Late Paleozoic Ice Age in Time and Space: Geological Society of America Special Paper 441, p. 115-129, https://doi .org/10.1130/2008.2441(08).

Holz, M., França, A.B., Souza, P.A., lannuzzi, R., and Rohn, R., 2010, A stratigraphic chart of the late Carboniferous/Permian succession of the eastern border of the Paraná Basin, Brazil, South America: Journal of South American Earth Sciences, v. 29, p. 381-399, https://doi .org/10.1016/ j.jsames.2009.04.004

Isbell, J.L., Henry, L.C., Gulbranson, E.L., Limarino, C.O., Fraiser, M.L., Koch, Z.J., Ciccioli, P.L., and Dineen, A.A., 2012, Glacial paradoxes during the late Paleozoic ice age: Evaluating the equilibrium line altitude as a control on glaciation: Gondwana Research, v. 22, p. 1-19, https://doi .org/10.1016/ j.gr.2011.11.005

Keller, C.B., Schoene, B., and Samperton, K.M., 2018, A stochastic sampling approach to zircon eruption age interpretation: Geochemical Perspectives Letters, v. 8, p. 31-35, https://doi .org/10.7185/geochemlet.1826.

Keller, C.B., Husson, J.M., Mitchell, R.N., Bottke, W.F., Gernon, T.M., Boehnke, P., Bell, E.A., Swanson- Hysell, N.L., and Peters, S.E., 2019, Neoproterozoic glacial origin of the Great Unconformity: Proceedings of the National Academy of Sciences of the United States of America, v. 116, p. 1136-1145, https://doi .org/10.1073/pnas.1804350116. 
Le Heron, D.P., Dietrich, P., Busfield, M.E., Kettler, C., Bermanschläger, S., and Grasemann, B., 2019, Scratching the surface: Footprint of a late Carboniferous ice sheet: Geology, v. 47, p. 1034-1038, https://doi .org/10.1130/ G46590.1.

Limarino, C.O., Cesari, S.N., Spalletti, L.A., Taboada, A.C., Isbell, J.L., Geuna, S., and Gulbranson, E.L., 2014, A paleoclimatic review of southern South America during the late Paleozoic: A record from icehouse to extreme greenhouse conditions: Gondwana Research, v. 25, no. 4, p. 1396-1421, https://doi .org/10.1016/ j.gr.2012.12.022

Linol, B., de Wit, M.J., Barton, E., de Wit, M.J.C., and Guillocheau, F., 2016, U-Pb detrital zircon dates and source provenance analysis of Phanerozoic sequences of the Congo Basin, central Gondwana: Gondwana Research, v. 29, p. 208-219, https://doi .org/10.1016/ j.gr.2014.11.009.

Martin, H., 1981, The late Paleozoic Dwyka Group of the South Kalahari Basin in Namibia and Botswana and the subglacial valleys of the Kaokoveld in Namibia, in Hambrey, M.J., and Harland, W.B., eds., Earth's Pre- Pleistocene Glacial Record: Cambridge, UK, Cambridge University Press, p. 61-66.

Mattinson, J.M., 2005, Zircon U-Pb chemical abrasion ("CA-TIMS") method: Combined annealing and multi-step partial dissolution analysis for improved precision and accuracy of zircon ages: Chemical Geology, v. 220, no. 1-2, p. 47-66, https://doi .org/10.1016/ j.chemgeo.2005.03.011.

Miller, R., 2008, The Geology of Namibia: Windhoek, Namibia, Geological Survey of Namibia, 3 p.

Montañez, I.P., and Poulsen, C.J., 2013, The late Paleozoic ice age: An evolving paradigm: Annual Review of Earth and Planetary Sciences, v. 41, p. 629-656, https://doi .org/10.1146/annurev.earth.031208.100118.

Piliouras, A., and Rowland, J.C., 2020, Arctic river delta morphologic variability and implications for riverine fluxes to the coast: Journal of Geophysical ResearchEarth Surface, v. 125, e2019JF005250, https://doi .org/10.1029/2019JF005250.

Richey, J.D., Montañez, I.P., Goddéris, Y., Looy, C., Griffis, N.P., and DiMichele, W.A., 2020, Influence of temporally varying weatherability on $\mathrm{CO}_{2}$-climate coupling and ecosystem change in the late Paleozoic: Climate of the Past, v. 16, p. 1759-1775, https://doi .org/10.5194/ cp-16-1759-2020.

Rino, S., Kon, Y., Sato, W., Maruyama, S., Santosh, M., and Zhao, D., 2008, The Grenvillian and Pan-African orogens: World's largest orogenies through geologic time, and their implications on the origin of superplume: Gondwana Research, v. 14, p. 51-72, https:// doi .org/10.1016/ j.gr.2008.01.001.

Rocha-Campos, A.C., Dos Santos, P.R., and Canuto, J.R., 2008, Late Paleozoic glacial deposits of Brazil: Paraná Basin, in Fielding, C.R., Frank, T.D., and Isbell, J.L., eds., Resolving the Late Paleozoic Ice Age in Space and Time: Geological Society of America Special Paper 441, p. 97-114, https://doi .org/10.1130/2008.2441(07).

Rocha-Campos, A.C., Basei, M.A.S., Nutman, A.P., Kleiman, L.E., Varela, R., Llambias, E., Canile, F.M., and da Rosa, O.C.R., 2011, 30 million years of Permian volcanism recorded in the Choiyoi igneous province (W Argentina) and their source for younger ash fall deposits in the Paraná Basin: SHRIMP U-Pb zircon geochronology evidence: Gondwana Research, v. 19, p. 509-523, https://doi .org/10.1016/ j.gr.2010.07.003.

Satkoski, A.M., Wilkinson, B.H., Hietpas, J., and Samson, S.D., 2013, Likeness among detrital zircon populations-An approach to the comparison of age frequency data in time and space: Geological Society of America Bulletin, v. 125, no. 11-12, p. 1783-1799, https://doi .org/10.1130/B30888.1.

Scheffler, K., Buehmann, D., and Schwark, L., 2006, Analysis of late Palaeozoic glacial to postglacial sedimentary successions in South Africa by geochemical proxies-Response to climate evolution and sedimentary environment: Palaeogeography, Palaeoclimatology, Palaeoecology, v. 240, p. 184-203, https://doi .org/10.1016/ j.palaeo.2006.03.059.

Schemiko, D.C.B., Vesely, F.F., and Rodrigues, M.C.N.L., 2019, Deepwater to fluvio-deltaic stratigraphic evolution of a deglaciated depocenter: The early Permian Rio do Sul and Rio Bonito formations, southern Brazil: Journal of South American Earth Sciences, v. 95, p. 102260, https://doi .org/10.1016/ j.jsames.2019.102260.

Schmitz, M.D., and Davydov, V.I., 2012, Quantitative radiometric and biostratigraphic calibration of the global Pennsylvanian-early Permian time scale: Geological Society of America Bulletin, v. 124, p. 549-577, https://doi .org/10.1130/B30385.1.

Schoene, B., 2014, U-Th-Pb geochronology, in Turekian, K.K., and Holland, H.D., eds., Treatise on Geochemistry (2nd ed.), Volume 4: The Crust: Amsterdam, Netherlands, Elsevier, p. 341-378, https://doi .org/10.1016/ B978-0-08-095975-7.00310-7.

Spencer, C.J., Kirkland, C.L., and Taylor, R.J.M., 2016, Strategies towards statistically robust interpretations of in situ U-Pb zircon geochronology: Geoscience Frontiers, v. 7, no. 4, p. 581-589, https://doi .org/10.1016/ j.gsf.2015.11.006.

Stollhofen, H., Werner, M., Stanistreet, I.G., and Armstrong, R.A., 2008, Single-zircon U-Pb dating of Carboniferous-Permian tuffs, Namibia, and the intercontinental deglaciation cycle framework, in Fielding, C.R., Frank, T.D., and Isbell, J.L., eds., Resolving the Late Paleozoic Ice Age in Time and Space: Geological Society of America Special Paper 441, p. 83-96, https://doi .org/10.1130/2008.2441(06)

Thomas, R.J., Spencer, C., Bushi, A.M., Baglow, N., Boniface, N., de Kock, G., Horstwood, M.S.A., Hollick, L., Jacobs, J., Kajara, S., Kamihanda, G., Key, R.M., Maganga, Z., Mbawala, F., McCourt, W., Momburi, P., Moses, F., Mruma, A., Myambilwa, Y., Roberts, N.M.W., Saidi, H., Nyanda, P., Nyoka, K., and Millar, I., 2016, Geochronology of the Central Tanzania craton and its southern and eastern orogenic margins: Precambrian Research, v. 277, p. 47-67, https://doi .org/10.1016/ j.precamres.2016.02.008.

Valdez Buso, V., Aquino, C.D., Paim, P.S.G., de Souza, P.A., Mori, A.L., Fallgatter, C., Milana, J.P., and Kneller, B., 2019, Late Palaeozoic glacial cycles and subcycles in western Gondwana: Correlation of surface and subsurface data of the Paraná Basin, Brazil: Palaeogeography, Palaeoclimatology, Palaeoecology, v. 531, p. 108435, https://doi .org/10.1016/ j.palaeo.2017.09.004

Vermeesch, P., Resentini, A., and Garzanti, E., 2016, An R package for statistical provenance analysis: Sedimentary Geology, v. 336, p. 14-25, https://doi .org/10.1016/ j.sedgeo.2016.01.009

Vesely, F.F., Trzaskos, B., Kipper, F., Assine, M.L., and Souza, P.A., 2015, Sedimentary record of a fluctuating ice margin from the Pennsylvanian of western Gondwana: Paraná Basin, southern Brazil: Sedimentary Geology, v. 326, p. 45-63, https://doi .org/10.1016/ j.sedgeo.2015.06.012.

Visser, J.N.J., 1987, The palaeogeography of part of southwestern Gondwana during the Permo-carboniferous glaciation: Palaeogeography, Palaeoclimatology, Palaeoecology, v. 61, p. 205-219, https://doi .org/10.1016/0031-0182(87)90050-2.

Visser, J.N.J., 1989, The Permo-Carboniferous Dwyka Formation of southern Africa: Deposition by a predominantly subpolar marine ice sheet: Palaeogeography, Palaeoclimatology, Palaeoecology, v. 70, p. 377-391, https://doi .org/10.1016/0031-0182(89)90115-6.

Visser, J.N.J., 1997, Deglaciation sequences in the Permo- Carboniferous Karoo and Kalahari basins of southern Africa: A tool in the analysis of cyclic glaciomarine basin fills: Sedimentology, v. 44, p. 507-521, https:// doi .org/10.1046/ j.1365-3091.1997.d01-35.x.

Werner, M., 2006, The Stratigraphy, Sedimentology, and Age of the Late Palaeozoic Mesosaurus Inland Sea, SW Gondwana-New Implications from Studies on Sediments and Altered Pyroclastic Layers of the Dwyka and Ecca Group (Lower Karoo Supergroup) in Southern Namibia [Ph.D. thesis]: Würzburg, Germany, University of Würzburg, 425 p., http://www.opusbayern.de/ uni-wuerzburg/volltexte/2007/2175/.

Zieger, J., Rothe, J., Hofmann, M., Gärtner, A., and Linnemann, U., 2019, The Permo-Carboniferous Dwyka Group of the Aranos Basin (Namibia)-How detrital zircons help understanding sedimentary recycling during a major glaciation: Journal of African Earth Sciences, v. 158, p. 103555, https://doi .org/10.1016/ j.jafrearsci.2019.103555.

Zieger, J., Stutzriemer, M., Hofmann, M., Gärtner, A., Gerdes, A., Marko, L., and Linnemann U., 2020, The evolution of the southern Namibian Karoo-aged basins: Implications from detrital zircon geochronologic and geochemistry data: International Geology Review (in press), https://doi .org/10.1080/00206814.2020.1 795732.

Science Editor: Brad S. Singer

Associate Editor: Alan Rooney

Manuscript Received 31 July 2020

Revised Manuscript Received 11 November 2020

Manuscript Accepted 3 December 2020

Printed in the USA 


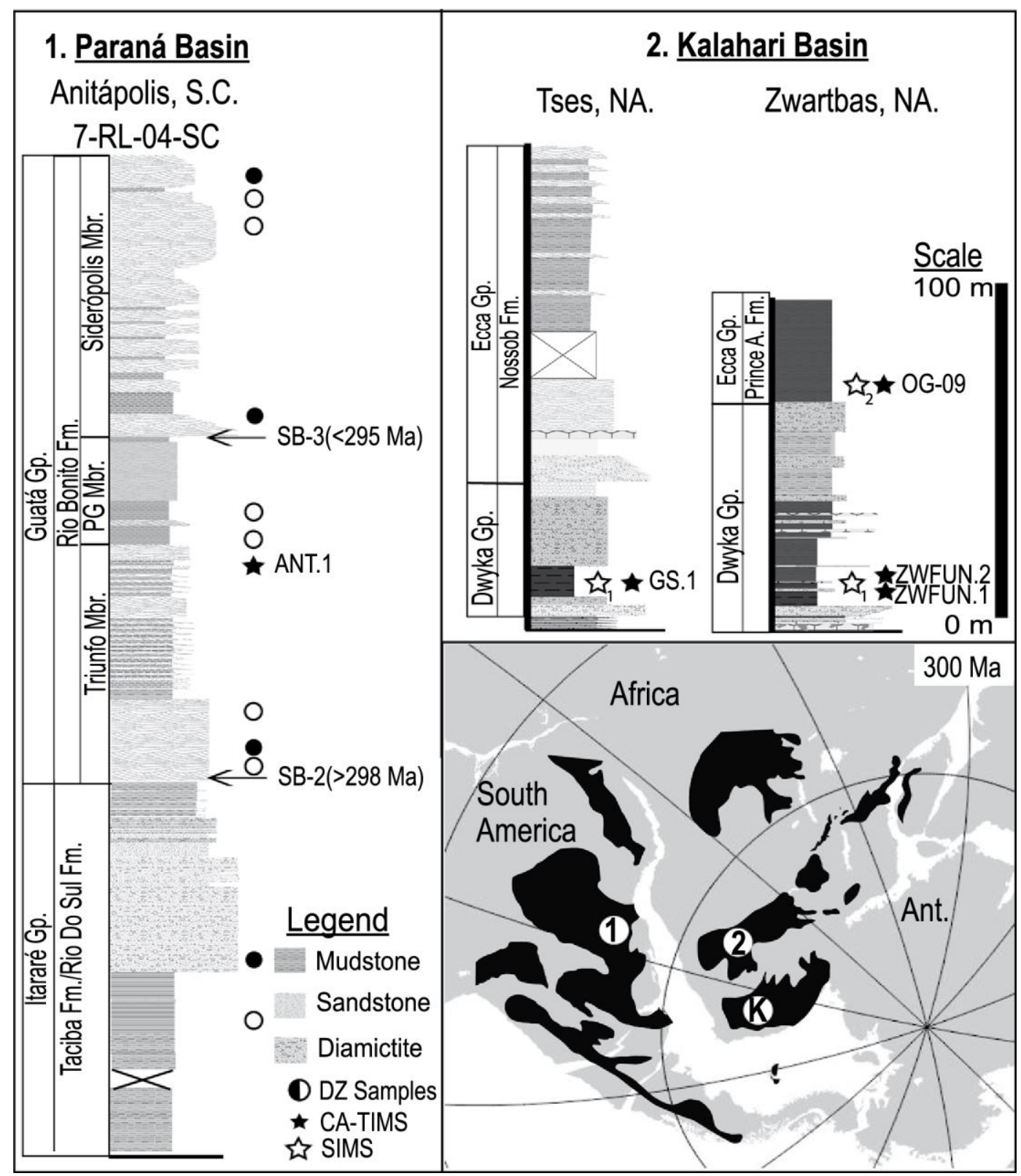

Figure 1 : Generalized stratigraphy for the Paraná and Kalahari Basins. 1-Paraná section from core 7-RL-04-SC, housed at the Universidade Federal Rio Grande do Sul, was retrieved proximal to the town of Anitápolis, Brazil; the core was not drilled into basement. Base of section reflects the extent of recovered material. 2-Kalahari sections are from the Aranos (Tses) and Karasburg (Zwartbas) subbasins. Filled stars-chemical abrasion-isotope dilution-thermal ionization mass spectrometry (CA-ID-TIMS) samples (this study; Griffis et al., 2019a [ANT 1]); open stars-approximate location of secondary ion mass spectrometry (SIMS) analysis ([1] Bangert et al., 1999; [2] Werner, 2006); black circles-detrital zircon (DZ) samples (this study); open circles-approximate stratigraphic locations of detrital zircon samples of Canile et al. (2016), which were sampled from the White Column locality. Stratigraphic columns from Paraná and Kalahari basins are drawn at the same scale. Gp-Group; Fm-Formation; Mbr-Member; SC-Santa Catarina, Brazil; NA-Namibia; Prince A-Prince Albert. Inset paleogeographic map (300 Ma) of SW Gondwana is after Domeier and Torsvik (2014): 1-Paraná Basin; 2-Kalahari Basin; K-Karoo Basin. Ant-Antarctica; PG-Paraguaçú mbr.. 


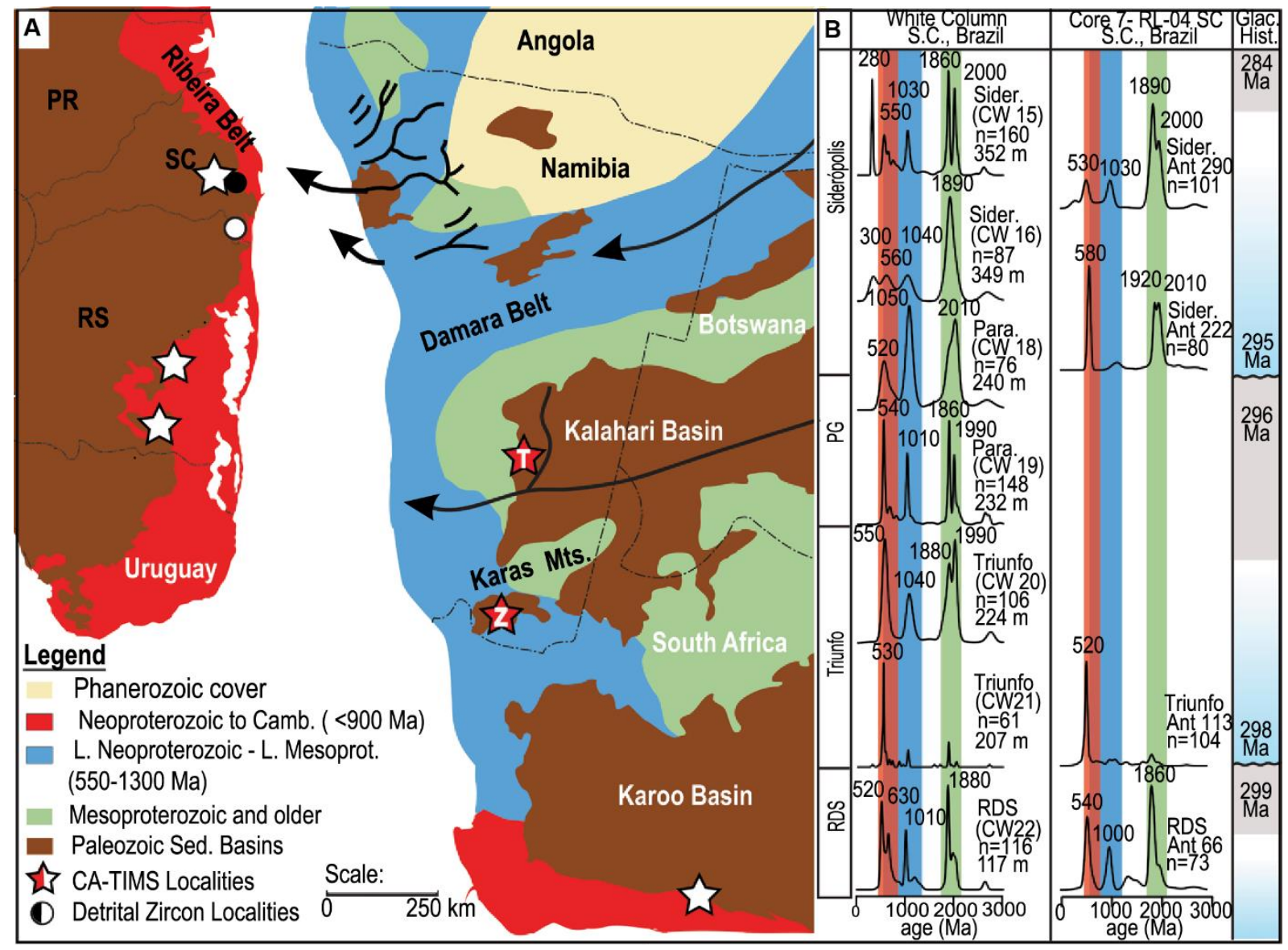

Figure 2 : A) Simplified geologic map of SW Gondwana (modified after Rino et al., 2008; Begg et al., 2009), showing glacial paleovalleys and paleoflow directions for Carboniferous and Permian sedimentary rocks across southern Africa (Visser, 1987; Martin, 1981; Bicca et al., 2017). White stars-published localities with chemical abrasion-isotope dilution-thermal ionization mass spectrometry (CA-ID-TIMS) age constraints for the late Paleozoic ice age (Griffis et al., 2018, 2019a); red stars—-new CA-ID-TIMS ages (this study). Z-Zwartbas (Karasburg Basin); T-Tses (Aranos Basin). White circle-White Column locality (Canile et al., 2016); black circle-7-RL-04-SC core. Depositional basins shown in brown: PR —Paraná State; SC—Santa Catarina State; RS—Rio Grande do Sul State. Camb—Cambrian. (B) Kernel density estimates of new zircon data (this study, ANT core samples) and existing data (White Column; Canile et al., 2016). Major peak ages are labeled. ${ }_{207} \mathrm{~Pb} /{ }_{206} \mathrm{~Pb}$ ages are presented for samples older than $1.4 \mathrm{Ga}$; ${ }_{206} \mathrm{~Pb} / 238 \mathrm{U}$ ages are presented for samples younger than $1.4 \mathrm{Ga}$. Color vertical shading corresponds to map colors in A: red bar-South American basement (<900 Ga); blue bar-southwest African basement (1.2-1.0 Ga); green bar-South American inheritance and southwest African basement (2.1-1.8 Ga). PG-Paraguaçú mbr.; RDS—Rio Do Sul. 


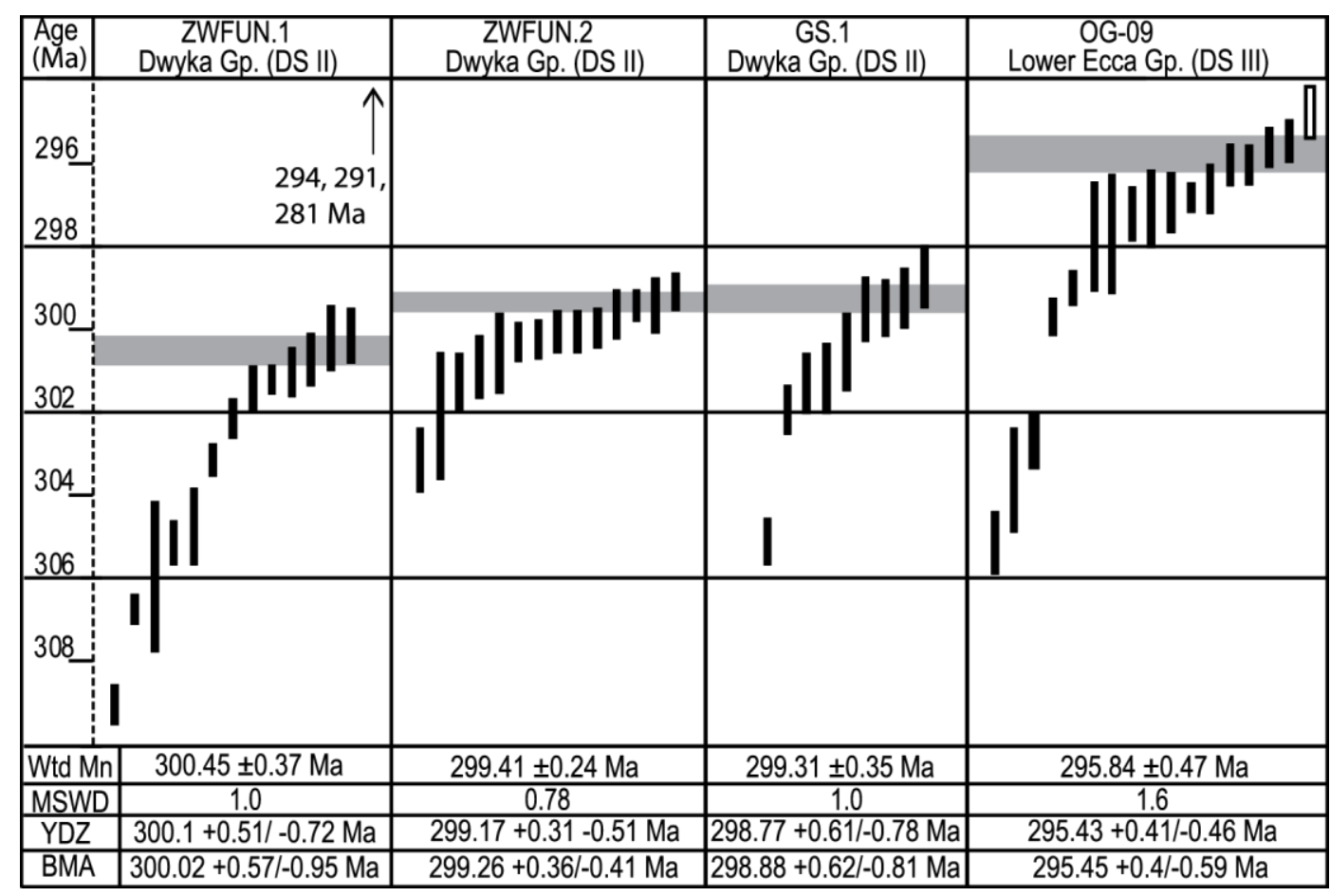

Figure 3 : New high-precision single-zircon ${ }_{206} \mathrm{~Pb} / 238 \mathrm{U}$ zircon ages for the Kalahari Basin, Namibia. Bars represent individual zircons and the analytical uncertainty $(2 \sigma)$. Three zircon grains from sample ZWFUN.1 plotted outside graph and were interpreted as $\mathrm{Pb}$ loss and excluded from the age calculation. Unfilled bar in OG-09 was interpreted as Pb loss and excluded from the age calculation. Gray band highlights weighted mean age for each sample (2 $\sigma)$. Wtd. Mnweighted mean age and the analytical uncertainty; MSWD—mean square weight of deviates; YDZ—youngest detrital zircon algorithm age; BMA—Bayesian model age. Gp_Group; DS II-DS III-deglaciation sequences II and III.

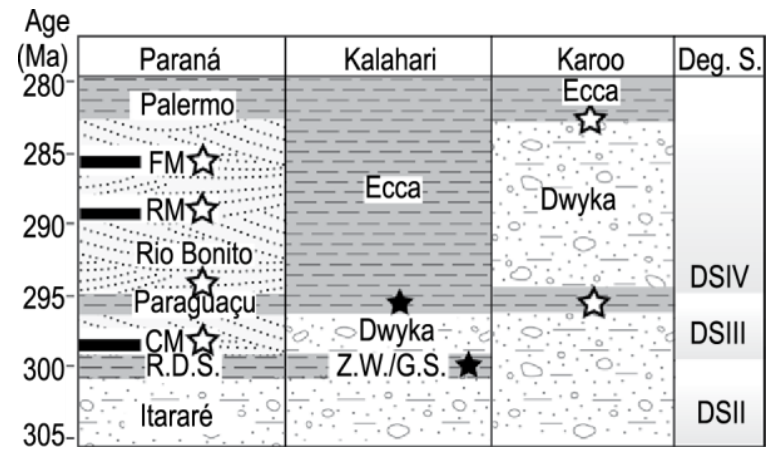

Figure 4 : Simplified stratigraphic framework for southwest Gondwana. Stars denote stratigraphic horizons calibrated with high-resolution U-Pb zircon chemical abrasion-isotope dilution-thermal ionization mass spectrometry (CA-ID-TIMS) analyses (filled stars-this study; open stars-Griffis et al., 2018, 2019a). Note the correlation of the Rio do Sul Formation (RDS) with the Zwartbas (Z.W.) and Ganigobis (G.S.) shales in Namibia and the Paraguaçu Member of the Rio Bonito Formation with the final glacial demise in Namibia and top of deglaciation sequence (DS) III in South Africa. CM-Candiota Mine; RM-Ricreo Mine; FM-Faxinal Mine. Deg. S. -deglaciation sequences (Visser, 1997). 


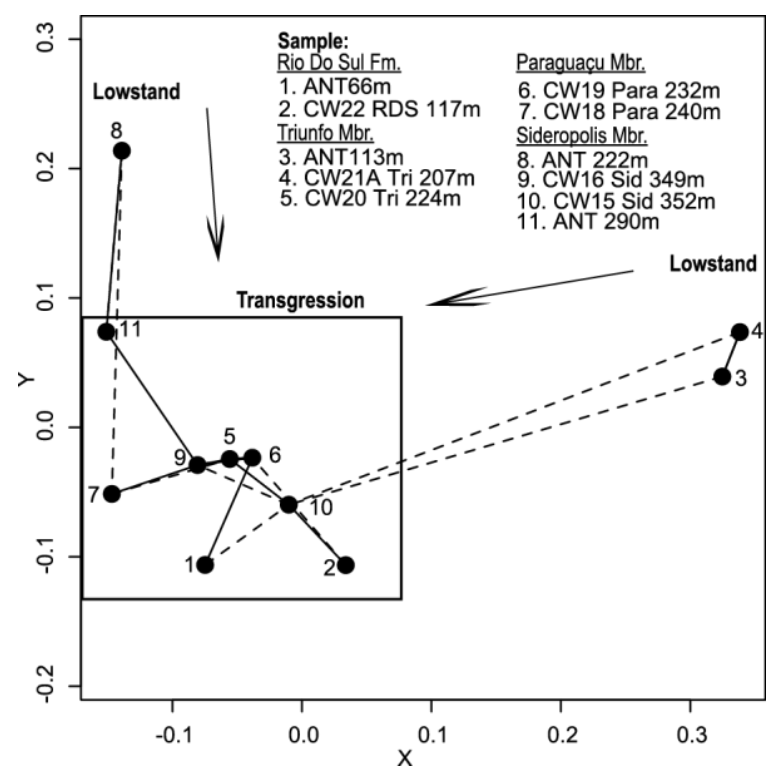

Figure 5: Multidimensional scaling plot of detrital zircon samples from the Rio do Sul Formation and the Triunfo, Paraguaçu, and Siderópolis Members of the Rio Bonito Formation in the Paraná Basin. The solid black lines connect nearest neighbors, and dashed lines connect second nearest neighbors, with the $\mathrm{x}$ and $\mathrm{y}$ dimensions representing the KolmogorovSmirnov (K-S) space between samples. Note the lowstand deposits $(3,4,8)$ plot away from the transgressive deposits. Detrital zircons from the transgressive deposits are tightly clustered. Sample numbers 2, 4, 5, 6, 7, 9, and 10 from Canile et al. (2016). Plot was constructed in $R$ using Provenance package 


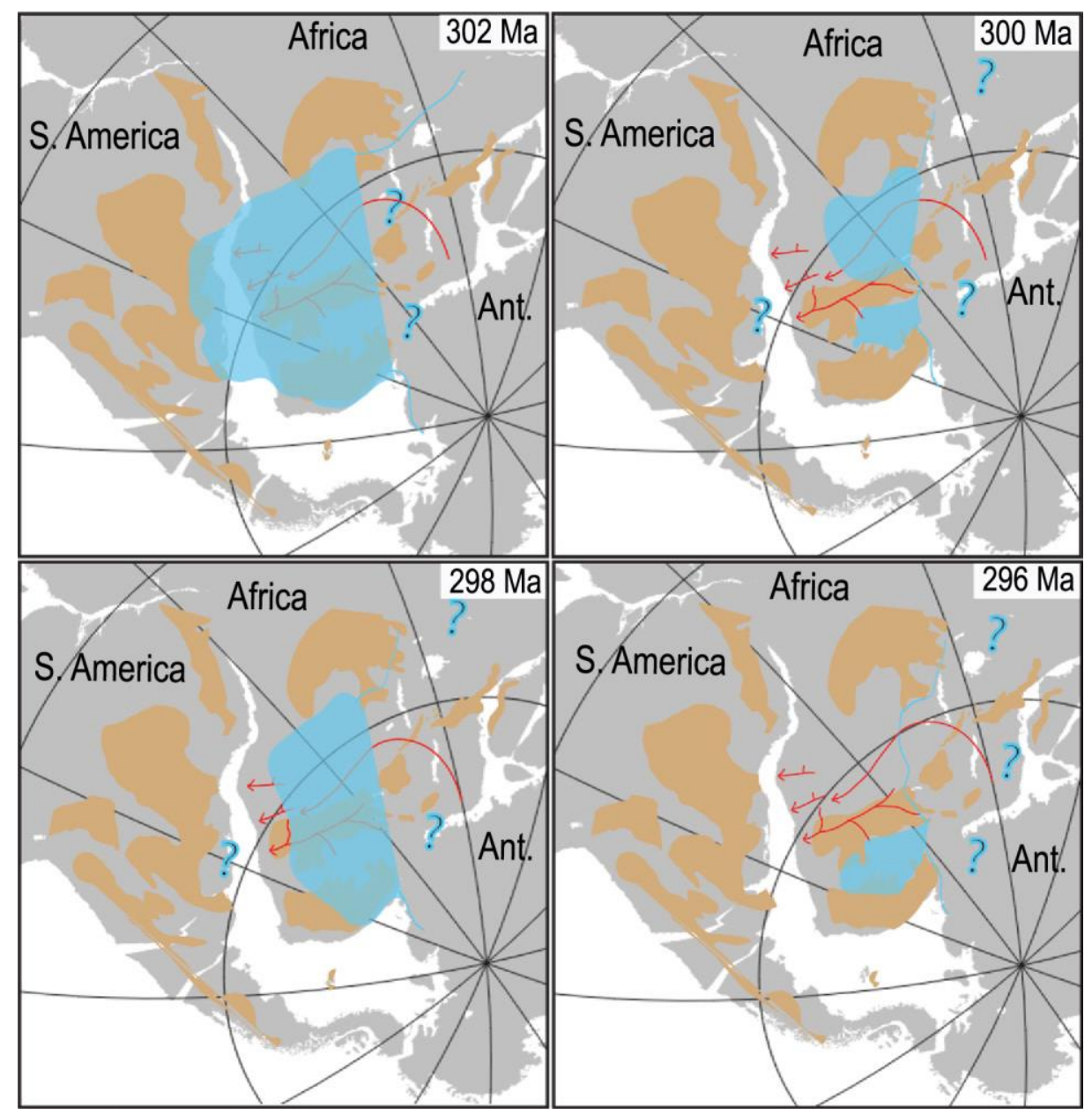

Figure 6 : Paleogeographic and ice reconstructions (blue) across the latest Carboniferous (302 Ma) through early Permian (296 Ma). Red arrows denote documented drainage reconstructions for southern Africa (Martin 1981; Visser, 1987; Bicca et al., 2017). Question marks are regions with well-documented late Paleozoic glacial records though no chemical abrasion-isotope dilution-thermal ionization mass spectrometry (CA-ID-TIMS) age control. Ant-Antarctica.

Table 1 : LIKENESS AND KOLMOGOROV-SMIRNOV (K-S) STATISTICAL RESULTS

TABLE 1. LIKENESS AND KOLMOGOROV-SMIRNOV (K-S) STATISTICAL RESULTS

\begin{tabular}{|c|c|c|c|c|c|c|c|c|c|c|c|}
\hline & $\begin{array}{c}\text { CW15 Sid. } \\
352 \text { m }\end{array}$ & $\begin{array}{c}\text { CW16 Sid. } \\
349 \text { m }\end{array}$ & $\begin{array}{c}\text { CW18 Para. } \\
240 \mathrm{~m}\end{array}$ & $\begin{array}{c}\text { CW19 Para. } \\
232 \mathrm{~m}\end{array}$ & $\begin{array}{c}\text { CW20 Tri. } \\
224 \mathrm{~m}\end{array}$ & $\begin{array}{l}\text { CW21A } \\
\text { Tri.207 m }\end{array}$ & $\begin{array}{c}\text { CW22 } \\
\text { RDS. } 117 \mathrm{~m}\end{array}$ & $\begin{array}{c}\text { ANT } \\
290 \mathrm{~m}\end{array}$ & $\begin{array}{l}\text { ANT } \\
222\end{array}$ & $\begin{array}{c}\text { ANT } \\
113\end{array}$ & $\begin{array}{c}\text { ANT } \\
66\end{array}$ \\
\hline CW15 Sid. $352 \mathrm{~m}$ & & 82.00 & 67.10 & 65.40 & 67.50 & 44.60 & 62.00 & 67.70 & 55.50 & 50.60 & 54.60 \\
\hline CW16 Sid. 349 m & 0.71 & & 61.10 & 65.70 & 65.70 & 42.40 & 61.40 & 70.40 & 49.40 & 47.70 & 57.20 \\
\hline CW18 Para. $240 \mathrm{~m}$ & 0.15 & 0.58 & & 64.10 & 65.20 & 40.20 & 56.70 & 59.60 & 49.50 & 46.80 & 52.40 \\
\hline CW19 Para. $232 \quad \mathrm{~m}$ & 0.17 & 0.43 & 0.27 & & 68.20 & 54.60 & 72.50 & 64.10 & 46.90 & $\begin{array}{l}40.00 \\
51.10\end{array}$ & 63.60 \\
\hline CW20Tri.224 m & 0.34 & 0.62 & 0.37 & 0.79 & & 49.80 & 64.60 & 65.20 & 55.00 & 52.60 & 56.20 \\
\hline CW21A Tri. 207 m & 0.00 & 0.00 & 0.00 & 0.00 & 0.00 & & 54.90 & 41.30 & 28.70 & 71.40 & 46.80 \\
\hline CW22RDS.117 m & 0.25 & 0.07 & 0.01 & 0.31 & 0.12 & 0.00 & & $\begin{array}{l}4.30 \\
58.20\end{array}$ & 43.10 & 54.00 & $\begin{array}{l}40.60 \\
58.60\end{array}$ \\
\hline $\begin{array}{l}\text { ANT } 290.111 \\
\text { Ans }\end{array}$ & 0.00 & 0.39 & 0.04 & 0.04 & 0.06 & 0.00 & 0.00 & & 51.90 & 38.10 & 63.80 \\
\hline ANT 222 & 0.00 & 0.04 & 0.07 & 0.01 & 0.01 & 0.00 & 0.00 & 0.36 & & 35.70 & 43.70 \\
\hline ANT 113 & 0.00 & 0.00 & 0.00 & 0.00 & 0.00 & 0.95 & 0.00 & 0.00 & 0.00 & & 44.80 \\
\hline ANT 66 & 0.42 & 0.69 & 0.47 & 0.65 & 0.68 & 0.00 & 0.05 & 0.12 & 0.00 & 0.00 & \\
\hline
\end{tabular}

Note: Likeness bin size $=2$ m.y. Kolmogorov-Smirnov (K-S) P values using error in the cumulative distribution function 